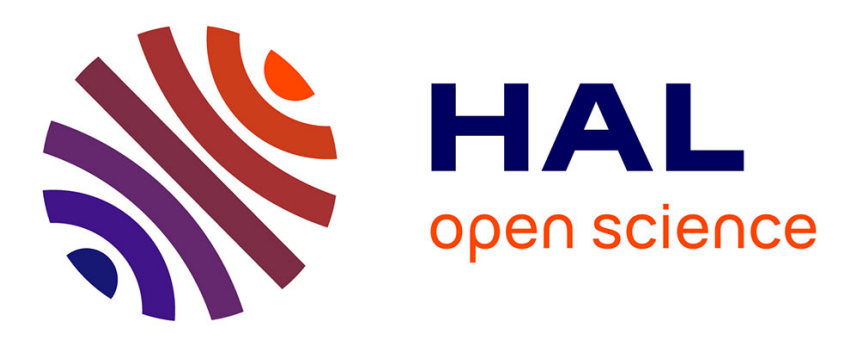

\title{
Experimental assessment of occurrences and stability of lead-bearing minerals in bacterial biofilms
}

Thaïs Couasnon, Alexandre Gélabert, Georges Ona-Nguema, Sandrine Zanna, Bénédicte Ménez, François Guyot

\section{- To cite this version:}

Thaïs Couasnon, Alexandre Gélabert, Georges Ona-Nguema, Sandrine Zanna, Bénédicte Ménez, et al.. Experimental assessment of occurrences and stability of lead-bearing minerals in bacterial biofilms. Chemical Geology, 2019, 505, pp.23-35. 10.1016/j.chemgeo.2018.11.023 . hal-02308498

\section{HAL Id: hal-02308498 \\ https://hal.sorbonne-universite.fr/hal-02308498}

Submitted on 8 Oct 2019

HAL is a multi-disciplinary open access archive for the deposit and dissemination of scientific research documents, whether they are published or not. The documents may come from teaching and research institutions in France or abroad, or from public or private research centers.
L'archive ouverte pluridisciplinaire HAL, est destinée au dépôt et à la diffusion de documents scientifiques de niveau recherche, publiés ou non, émanant des établissements d'enseignement et de recherche français ou étrangers, des laboratoires publics ou privés. 


\section{Accepted Manuscript}

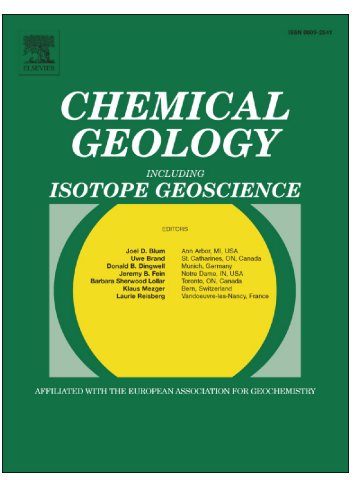

Thaïs Couasnon, Alexandre Gélabert, Georges Ona-Nguema, Sandrine Zanna, Bénédicte Ménez, François Guyot

Experimental assessment of occurrences and stability of leadbearing minerals in bacterial biofilms

PII: $\quad$ S0009-2541(18)30583-7

DOI: $\quad$ https://doi.org/10.1016/j.chemgeo.2018.11.023

Reference: $\quad$ CHEMGE 18985

To appear in: $\quad$ Chemical Geology

Received date: $\quad 15$ May 2018

Revised date: $\quad 22$ July 2018

Accepted date: $\quad 28$ November 2018

Please cite this article as: Thaïs Couasnon, Alexandre Gélabert, Georges Ona-Nguema, Sandrine Zanna, Bénédicte Ménez, François Guyot, Experimental assessment of occurrences and stability of lead-bearing minerals in bacterial biofilms. Chemge (2018), https://doi.org/10.1016/j.chemgeo.2018.11.023

This is a PDF file of an unedited manuscript that has been accepted for publication. As a service to our customers we are providing this early version of the manuscript. The manuscript will undergo copyediting, typesetting, and review of the resulting proof before it is published in its final form. Please note that during the production process errors may be discovered which could affect the content, and all legal disclaimers that apply to the journal pertain. 


\title{
Experimental assessment of occurrences and stability of lead-bearing minerals in bacterial biofilms
}

\author{
Thaïs Couasnon ${ }^{\mathrm{a}, *}$, Alexandre Gélabert ${ }^{\mathrm{a}}$, Georges Ona-Nguema ${ }^{\mathrm{b}}$, Sandrine Zanna ${ }^{\mathrm{c}}$, \\ Bénédicte Ménez ${ }^{\mathrm{a}}$, François Guyot ${ }^{\mathrm{b}}$
}

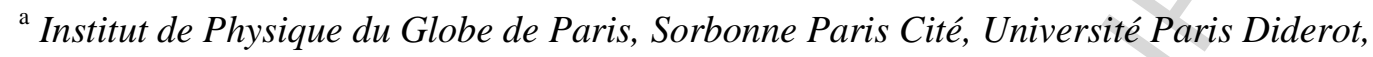
UMR 7154 CNRS, 75238 Paris Cedex 05, France

${ }^{\mathrm{b}}$ Institut de Minéralogie, de Physique des Matériaux et de Cosmochimie, Sorbonne-

Université, IRD, Museum National d'Histoire Naturelle, UMR 7590 CNRS, Campus Pierre et Marie Curie, 75252 Paris Cedex 05, France

${ }^{\mathrm{c}}$ Physico Chimie des Surfaces, Chimie Paris, 75005 Paris, France

* Corresponding author. E-mail address: couasnon@ipgp.fr (T. Couasnon).

\section{ARTICLE INFO}

Keywords:

Biomineralization

Biofilm

Metal dynamics

Lead

Microenvironments 


\section{ABSTRACT}

Bio-induced precipitation of lead-bearing minerals is investigated in bacterial biofilms grown by Shewanella oneidensis MR-1 under aerobic conditions. Under the different conditions investigated, thermodynamic calculations establish that the stable mineral phases expected to precipitate are either wulfenite $\mathrm{PbMoO}_{4}$ or cerussite $\mathrm{PbCO}_{3}$. However, observations by electron microscopy show that the first solids precipitated within hours at the experimental solution/biofilm interface are crystals of about $20 \mathrm{~nm}$ in diameter of pyromorphite $\mathrm{Pb}_{5}\left(\mathrm{PO}_{4}\right)_{3}(\mathrm{OH}, \mathrm{Cl})$. In Mo-bearing systems, the precipitation of the thermodynamicallypredicted wulfenite phase is delayed compared to the abiotic experiment and is observed only after 7 days of lead exposure. The initial lead phosphate crystals observed on the extracellular polymeric substances are assumed to result from concurrent local abundances of adsorbed $\mathrm{Pb}^{2+}$ ions and phosphate groups released by metabolically active cells. Scanning electron microscopy observations of samples milled by focused ion beam reveal effective diffusionlimited precipitation of pyromorphite within the well-preserved biofilm porosity. 


\section{Introduction}

Lead is one of the most common pollutants in soils due to anthropic activities. Lead extraction from mines is widespread and still on the rise over the world: from 2343000 tons in 1996 (Laperche et al., 2004) to 5500000 of tons in 2014 (U.S. Geological Survey, 2015). Other concentrated spots of lead emerge because of its widespread use in, among others, batteries (Haefliger et al., 2009), paintings, old canalizations and ammunitions (Laperche et al., 2004). Associated recycling is also responsible for high accumulations of lead: in 2014, about 1150000 tons of secondary lead was produced (U.S. Geological Survey, 2017). Lead belongs to the thirteen trace metals and metalloids that are considered as priority pollutants (i.e., $\mathrm{Ag}, \mathrm{As}, \mathrm{Be}, \mathrm{Cd}, \mathrm{Cr}, \mathrm{Cu}, \mathrm{Hg}, \mathrm{Ni}, \mathrm{Pb}, \mathrm{Sb}, \mathrm{Se}, \mathrm{Tl}, \mathrm{Zn}$; Sparks, 2005). Lead diffuses directly from these high-concentration 'hotspots' or spreads through rivers into environments in contact with humans. The worldwide abundance of manufactured lead associated with its toxicity emphasize the need to understand the mechanisms and processes controlling its environmental cycle.

The toxicity of lead depends on its bioavailability for humans, animals, plants and microorganisms. It relates to the mobility of lead species, which can be reduced when lead is transformed into stable mineral forms. One of the most stable and insoluble forms of lead known in soils is pyromorphite $\mathrm{Pb}_{5}\left(\mathrm{PO}_{4}\right)_{3}(\mathrm{OH}, \mathrm{Cl})$ (Ruby et al., 1994). Accordingly, introduction of large amounts of phosphate ions in lead-polluted soils is commonly used as a remediation approach (Hettiarachchi et al., 2001). Pyromorphite is sometimes found associated with wulfenite, a lead molybdate $\mathrm{PbMoO}_{4}$, which is also very stable; both compounds are found in lead mines (Fransolet et al., 1978). Improving the knowledge of the factors controlling lead speciation is mandatory to predict the fate of this pollutant in the environment and to control its toxicity to ecosystems and humans. 
In the environment, the interface between mineral and aqueous phases is responsible for the speciation of dissolved chemical components and secondary mineral phases (Brown and Calas, 2011). In numerous environments, this interface is colonized by microbial biofilms, which are three-dimensional porous structures made of microbial cells interconnected by extracellular polymeric substances (EPS) (Flynn et al., 2013). The abundance of biofilms in a broad range of environments highlights the importance of improving our knowledge concerning their action on the chemistry of pollutants and, in particular, on metal immobilization into insoluble minerals. Mineral nucleation and precipitation can indeed be favored by abundant metal-binding sites in the microbial cell outer-membrane or in the EPS (Brown and Calas, 2012). Mineralization on EPS produced by cells in biofilms frequently occurs in natural environments (Benzerara et al., 2011; Chan et al., 2009; Ghiorse, 1984; Miot et al., 2009). When biofilms are exposed to lead, it has been reported in the case of Burkholderia cepacia species that $\mathrm{Pb}^{2+}$ from aqueous solutions transforms into the stable mineral phase pyromorphite. The latter forms under environmental conditions where lead precipitation is not predicted to occur in the bulk aqueous phase (Templeton et al., 2001). Although the mechanisms of lead phosphate formation by $B$. cepacia are still unknown, these authors have shown that the formation of pyromorphite is always associated with cell surfaces and requires metabolically active microorganisms.

In biofilms, active microbial cells along with variable porosity and permeability in EPS lead to the formation of microenvironments (Costerton et al., 1995). These latter are characterized by variable $\mathrm{pH}$, concentrations of nutrients, $\mathrm{O}_{2}$ partial pressure $\left(\mathrm{pO}_{2}\right)$, organic compounds or quorum sensing molecules released by the biofilm-forming microbial community (Stewart and Franklin, 2008). These microenvironments can favor lead adsorption and precipitation reactions. In addition, mineral dissolution and precipitation of secondary minerals have been recently shown in biofilms for minerals containing platinum group elements (Reith et al., 2016) or in the case of gold biomineralization (Reith et al., 2010). 
Knowledge of the microenvironments where precipitation and dissolution phenomena occur is hence mandatory to understand and quantitatively assess lead immobilization in biofilms but it remains a highly difficult task. The challenge in studying biomineralization in biofilms lies in the need to perform observations and characterizations at the cell scale in a highly fragile structure whose tri-dimensional (3D) organization has to be preserved (van Hullebusch et al., 2003).

The purpose of the present study was to investigate lead-bearing minerals formed over time in bacterial biofilms in order to better assess the fate of lead within the evolving microenvironments found in biofilms. To do so, a mineralization medium was designed to provide all the nutrients needed for the bacteria to thrive during lead exposure experiments. Its simple composition also allowed to control and model chemical reactions and hence mineralization processes at the biofilm-solution interface. Axenic Shewanella oneidensis MR1 biofilms, as a simplified representation of biofilms in natural systems, were immersed in this mineralization medium supplemented with $\mathrm{Pb}^{2+}$ at various concentrations. The Gramnegative $S$. oneidensis bacteria was chosen as a common strain ubiquitously found in soils, sediments and aquifers. It is a facultative anaerobe able to use $\mathrm{O}_{2}$ for respiration under oxic conditions. Significant uptake of $\mathrm{Pb}$ leading to the formation of pyromorphite has been previously shown in a single layer (i.e., one cell layer) Burkholderia cepacia biofilm where no precipitation of competing thermodynamically-stable minerals was predicted to occur on the basis of bulk aqueous chemistry (Templeton et al., 2001). Conversely, our experimental conditions were set so that either wulfenite or cerussite was the thermodynamically-stable phase that should precipitate from the aqueous phase. These mineral phases were hence in direct competition with the previously-observed pyromorphite. To accurately determine locations where precipitation of the different solid phases occurred, we successfully carried out scanning electron microscopy (SEM) observations of well preserved biofilm crosssections thanks to focused ion beam (FIB) milling. Observations using this technique have 
already been done on natural biofilm samples containing biomineralizations of gold (Reith et al., 2010) and iron oxyhydroxides (Toner et al., 2009) but never reached such a preservation state of the 3D structure, hence providing promising new approaches for future work. Overall, this study allowed to highlight the role of local microenvironments in controlling the nature and fate of lead-bearing minerals in the biofilm porosity. Broader assessment of the implications in the environment would help to evaluate long term bioavailability of potentially toxic aqueous lead.

\section{Materials and methods}

\subsection{Shewanella oneidensis MR-1 biofilm culture}

Shewanella oneidensis MR-1 biofilms were grown on $\alpha-\mathrm{Al}_{2} \mathrm{O}_{3}$ single crystal substrates (PI-KEM Ltd) following a protocol adapted from Wang et al. (2016). This latter study investigated at the macroscale the competitive sorption between $\mathrm{Pb}$ and $\mathrm{Zn}$ ions at $S$. oneidensis biofilm/metal-oxide/water interfaces. It hence provided a relevant background and notably $\mathrm{Pb}^{2+}$ depth profiles within a biofilm. $\alpha-\mathrm{Al}_{2} \mathrm{O}_{3}$ also shares surface properties with clays, of large occurrence in soils (Clausen et al., 2001).

Prior to biofilm growth, all substrates were carefully cleaned using acetone, then washed in $10^{-3.5} \mathrm{M}$ sodium hydroxide for $20 \mathrm{~min}$, and immersed in $10^{-2} \mathrm{M}$ nitric acid for 20 additional minutes. Each cleaning stage was followed by three rinses using Milli-Q ${ }^{\circledR}$ water (resistivity $=18 \mathrm{M} \Omega \cdot \mathrm{cm}$ ). All crystalline substrates and tubing were wet-heat sterilized (45 min at $121^{\circ} \mathrm{C}$ ) before use. $500 \mathrm{~mL}$ of a $S$. oneidensis MR-1 culture grown in trypticase soy broth nutrient-rich medium (Sigma-Aldrich) were harvested in their late exponential phase at an optical density of 1.2 at $600 \mathrm{~nm}$. The alumina crystals were immersed in this bacterial suspension during $1 \mathrm{~h}$ to allow cell attachment onto the substrates. Then, a minimal culture 
medium flow $\left(24 \mathrm{~mL} \cdot \mathrm{h}^{-1}\right)$ was imposed to the system during 20 days for biofilm to grow under aerobic conditions. The minimal culture medium was composed of $5 \cdot 10^{-3} \mathrm{mM} \mathrm{CoCl}_{2}$, $2 \cdot 10^{-4} \mathrm{mM} \mathrm{CuSO}_{4}, 5.7 \cdot 10^{-2} \mathrm{mM} \mathrm{H}_{3} \mathrm{BO}_{3}, 1 \mathrm{mM} \mathrm{MgSO} 4,1.3 \cdot 10^{-3} \mathrm{mM} \mathrm{MnSO}_{4}, 3.9 \cdot 10^{-3} \mathrm{mM}$ $\mathrm{Na}_{2} \mathrm{MoO}_{4}, 1.5 \cdot 10^{-3} \mathrm{mM} \mathrm{Na}_{2} \mathrm{SeO}_{4}, 150 \mathrm{mM} \mathrm{NaCl}, 2 \mathrm{mM} \mathrm{NaHCO}{ }_{3}, 9 \mathrm{mM}\left(\mathrm{NH}_{4}\right)_{2} \mathrm{SO}_{4}, 5 \cdot 10^{-3}$ $\mathrm{mM} \mathrm{NiCl}_{2}, 1 \cdot 10^{-3} \mathrm{mM} \mathrm{ZnSO}_{4}, 1.3 \mathrm{mM} \mathrm{K}_{2} \mathrm{HPO}_{4}$, and 7.3 $10^{-1} \mathrm{mM} \mathrm{KH}_{2} \mathrm{PO}_{4}$ (all being highpurity grade from Sigma-Aldrich). The $\mathrm{pH}$ was buffered with $5 \mathrm{mM}$ 4-(2-hydroxyethyl)-1piperazineethanesulfonic acid (HEPES) and adjusted to 7 for optimal growth conditions. This medium was then autoclaved, and, once the solution cooled down, sterile Na-lactate and $\mathrm{CaCl}_{2}$ solutions were added to reach final concentrations of $1.5 \cdot 10^{-1}$ and $6.4 \cdot 10^{-1} \mathrm{mM}$, respectively. After growth, biofilm-coated substrates were carefully collected and immediately used under sterile conditions for lead exposure experiments.

\subsection{Lead exposure experiments}

In order to identify the parameters controlling lead mineralization in S. oneidensis MR-1 biofilms, two distinct exposure experiments were performed. The first experimental conditions aimed at promoting the formation of thermodynamically-favored wulfenite precipitates. To achieve this goal, biofilms coating the alumina chips were gently rinsed three times using Milli- $\mathrm{Q}^{\circledR}$ water and exposed to $40 \mathrm{~mL}$ of a sterilized solution, hereafter referred to as mineralization medium. It was composed of $5 \cdot 10^{-3} \mathrm{mM} \mathrm{CoCl}_{2}, 2 \cdot 10^{-4} \mathrm{mM} \mathrm{CuSO}_{4}, 5.7 \cdot 10^{-4}$ $\mathrm{mM} \mathrm{H}_{3} \mathrm{BO}_{3}, 5 \cdot 10^{-1} \mathrm{mM} \mathrm{MgSO}_{4}, 1.3 \cdot 10^{-3} \mathrm{mM} \mathrm{MnSO}_{4}, 3.9 \cdot 10^{-3} \mathrm{mM} \mathrm{Na}_{2} \mathrm{MoO}_{4}, 1.5 \cdot 10^{-3} \mathrm{mM}$

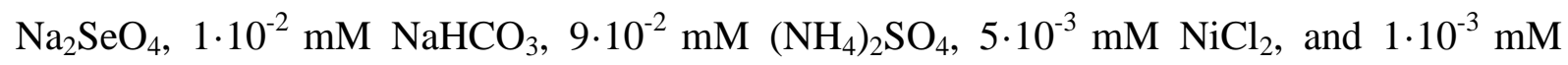
$\mathrm{ZnSO}_{4}, 1.5 \cdot 10^{-1} \mathrm{mM} \mathrm{KNO}{ }_{3}, 1.5 \cdot 10^{-1} \mathrm{mM} \mathrm{Na}$-lactate and $2 \cdot 10^{-1} \mathrm{mM} \mathrm{CaCl}_{2}$ (all being highpurity grade from Sigma Aldrich). With the exception of phosphate ions, this mineralization medium contains all the nutrients necessary for the bacteria to thrive over a week of lead exposure (i.e., a carbon source and trace elements). The medium composition was also 
designed to allow a control of the number of chemical parameters in our experimental systems and model its evolution through time for an accurate investigation of the mineralization processes. From that perspective, the mineralization medium used here was not designed to mimic any specific environmental system. Three different concentrations of $\mathrm{Pb}\left(\mathrm{NO}_{3}\right)_{2}$ were added to this medium: $10^{-7} \mathrm{M}$ and $10^{-6} \mathrm{M}$, which are representative of polluted environments (Laperche et al., 2004), and $10^{-4} \mathrm{M}$, a high concentration aiming at enhancing the biomineralization phenomena and hence at better understanding the driving forces at work and assessing the biomineralization mechanisms.

Precipitation is predicted to potentially occur in solution for positive values of the Saturation Index (SI) defined as:

$\mathrm{SI}=\log \left(\mathrm{IAP} / \mathrm{K}_{\mathrm{sp}}\right)$

where IAP is the ion activity product, and $\mathrm{K}_{\mathrm{sp}}$ is the thermodynamic solubility product of the considered solid phase. The solution is supersaturated with respect to this phase when IAP > $\mathrm{K}_{\mathrm{sp}}$, and precipitation is then thermodynamically favored. Supersaturations relative to the $\mathrm{Pb}$ bearing mineral phases that were the most likely to precipitate in our experiments were checked using Thermoddem database in Visual Minteq v3.0 (Blanc et al., 2012). The considered values of equilibrium constants are listed in Supplementary data Table A1. Activity coefficients were calculated using the Debye-Hückel approach. $\mathrm{pH}$ of the mineralization media was then defined according to the thermodynamic calculations to solely promote under thermodynamic control the precipitation of wulfenite (Fig. 1). Accordingly, the $\mathrm{pH}$ of the mineralization medium containing $\mathrm{Pb}^{2+}$ at $10^{-4} \mathrm{M}$ was adjusted to $6.0 \pm 0.1 \mathrm{using}$ diluted $\mathrm{NaOH}$ and $\mathrm{HNO}_{3}$ solutions while mineralization media with $\mathrm{Pb}^{2+}$ at $10^{-6} \mathrm{M}$ and $10^{-7} \mathrm{M}$ were adjusted to $\mathrm{pH} 7.0 \pm 0.1$.

In the second set of experiments, biofilm-coated substrates were only exposed to leaddoped solutions of $\mathrm{NaNO}_{3}$ at $10^{-2} \mathrm{M}$. Similar lead concentrations and $\mathrm{pH}$ as in the sterilized 
mineralization medium were used (i.e., $10^{-7} \mathrm{M}$ and $10^{-6} \mathrm{M}$ at $\mathrm{pH} 7.0 \pm 0.1$, and $10^{-4} \mathrm{M}$ at $\mathrm{pH}$ $6.0 \pm 0.1)$

Exposure times ranged between 1 hour and 7 days and during experiments, the evolution of the biofilm structure was assessed by confocal laser scanning microscopy (CLSM) using a FluoView ${ }^{\mathrm{TM}}$ FV1000 microscope (Olympus) at IPGP (Paris, France). Under both experimental conditions, no significant biofilm degradation was noticeable after 7 days of lead exposure.

Abiotic control experiments were also performed. They consisted in $\alpha-\mathrm{Al}_{2} \mathrm{O}_{3}$ single crystals exposed either to the mineralization medium or to the $\mathrm{NaNO}_{3}$ solution, both containing lead at the concentrations of interest (i.e., $10^{-4} \mathrm{M}$ and $10^{-6} \mathrm{M}$ of $\mathrm{Pb}^{2+}$ ).

For all experiments, $\mathrm{pH}$ evolution in the supernatant was monitored. Temporal evolutions of total lead and molybdenum concentrations in the supernatant were measured by inductively coupled plasma-quadrupole mass spectrometry (ICP-QMS) using an Agilent 7900 apparatus (IPGP, Paris, France). For this purpose, a volume of $0.250 \mathrm{~mL}$ of supernatant was sampled at different exposure times: $15 \mathrm{~min}, 30 \mathrm{~min}$, every $30 \mathrm{~min}$ until $4 \mathrm{~h}, 6 \mathrm{~h}, 9 \mathrm{~h}, 1$ day, 2.5 days, 3 days, and 7 days. The sampled solutions were acidified using bi-distilled $\mathrm{HNO}_{3}$, and stored at $4{ }^{\circ} \mathrm{C}$ until analysis. Saint Laurent river certified water (SLRS4) was used as an external reference during ICP-QMS measurements. Typical detection limits for $\mathrm{Pb}$ and $\mathrm{Mo}$ ICP-QMS measurements are $1 \mathrm{ppt}$ for $\mathrm{Pb}$ and $2 \mathrm{ppt}$ for Mo.

\subsection{Electron microscopy}

In order to characterize mineral precipitates in the biofilm structure, scanning and transmission electron microscopy analyses were performed. As summarized in Table 1, three different exposure times were investigated by SEM: 1 h, 1 day, and 7 days. Manipulations and observations of the biofilms were challenging, mainly because of their fragility and organic 
nature. Special care was taken to minimize the impact of sample preparation prior to electron microscopy observations (van Hullebusch et al., 2003). At sampling times, biofilm-coated substrates were gently removed from the experimental solutions and the biofilms were immediately dried. To do so, samples were subjected to successive dehydration steps in ethanol-water (50-50, 75-25, 90-10 and 100-0) baths, and then to critical point drying using $\mathrm{CO}_{2}$ (Leica EM CPD300). No fixation step or contrasting agents that would have modified the mineral-solution equilibrium were used. Afterwards, a $15 \mathrm{~nm}$ thick conductive carbon coating was deposited on the dried biofilms by high vacuum sputter coating (Leica EM SCD500). Samples were then observed using a Zeiss Ultra 55 scanning electron microscope (IMPMC, Paris, France) equipped with a field emission gun (FEG). Two types of detectors were used: a low energy backscattered electron (BSE) detector (down to $2 \mathrm{kV}$ ) to image chemical contrasts, and secondary electron (SE) detectors (down to $5 \mathrm{kV}$ ) to collect topographic information. In addition, the microscope was equipped with an energy dispersive X-ray spectrometer (EDXS).

In order to investigate the presence of precipitates in the biofilm thickness, crosssections were milled by FIB on selected samples (Table 1) under mild conditions to avoid as much as possible local damages. Sections were obtained using an Auriga ${ }^{\circledR}$ FEG-FIB (IPGP, Paris, France) consisting in a $\mathrm{Ga}^{+}$beam produced from a Ga liquid metal ion source operating at $30 \mathrm{kV}$ and $20 \mathrm{pA}$. Those parameters were sufficient to cut the dried biofilm to a final thickness of $3 \mu \mathrm{m}$ without damaging it. Immediately after FIB milling, sections were carbon coated, prior to SEM investigations using secondary electron \pm secondary ion (SESI and Inlens) detectors.

Transmission electron microscopy (TEM) analyses were performed using a $200 \mathrm{kV}$ FEG-JEOL2100F microscope equipped with an EDXS system necessary to detect the elements of interest (i.e., Mo $\mathrm{K} \alpha$ at $17.44 \mathrm{keV}$ and $\mathrm{Pb} \mathrm{L} \alpha$ at $10.55 \mathrm{keV}$ ). For analysis, biofilms were gently scratched from the alumina substrates using a clean scalpel, and then deposited 
on a TEM C-coated copper grid. A $15 \mathrm{~nm}$ thick carbon film was then deposited on the sample prior to analyses. Even if this preparation procedure modifies the $3 \mathrm{D}$ arrangement of the bacterial biofilm at a large scale, the local structure (at the scale of tens of nanometers) is preserved and can still be studied. Selected area electron diffraction (SAED) patterns were collected to characterize the mineral phases. To identify lead precipitates, SAED patterns were compared to the International Centre for Diffraction Data (ICDD) database of standard X-ray diffraction reference patterns.

\subsection{X-ray photoelectron spectrometry}

X-ray photoelectron spectrometry (XPS) was performed using a Thermo Fisher Scientific Escalab 250 spectrometer with the monochromatized Al Ka radiation (1486.6 eV). Samples consisted in non-metalized critical point dried biofilms exposed for $24 \mathrm{~h}$ to $\mathrm{Pb}^{2+}$ at concentrations of $10^{-4} \mathrm{M}$ and $10^{-6} \mathrm{M}$ and for $1 \mathrm{~h}$ at $10^{-4} \mathrm{M} \mathrm{Pb}^{2+}$ (Table 1). Triplicate analysis of areas of $500 \mu \mathrm{m}^{2}$ in size were carried out. The following core levels were analyzed: $\mathrm{O} 1 \mathrm{~s}, \mathrm{C} 1 \mathrm{~s}$, $\mathrm{N} 1 \mathrm{~s}, \mathrm{Al} 2 \mathrm{p}, \mathrm{P} 2 \mathrm{p}, \mathrm{Pb} 4 \mathrm{f}$. The photoelectron take-off angle was $90^{\circ}$. The analyzer pass energy was $100 \mathrm{eV}$ for survey spectra and $20 \mathrm{eV}$ for high resolution spectra. The electron binding energy of the acquired spectra was calibrated using the $\mathrm{C} 1 \mathrm{~s}$ level at $285 \mathrm{eV}$ as an internal standard. Spectra were fitted with the Thermo Scientific ${ }^{\mathrm{TM}}$ Avantage software. To estimate surface composition, the inelastic mean free paths calculated by QUASES-IMFP TPP2M 3.0 software with an energy source of $1486.6 \mathrm{eV}$ and the photoemission cross sections determined by Scofield (1976) were used. 


\section{Results}

\subsection{Abiotic controls}

As previously stated, thermodynamic calculations were run to define the $\mathrm{pH}$ conditions at which the mineralization medium promotes solely wulfenite precipitation at total lead concentrations of $10^{-4}, 10^{-6}$ and $10^{-7} \mathrm{M}$. Calculation results are reported in Figs. 1a-c, which show for the mineralization medium a positive saturation index for wulfenite $\left(\mathrm{PbMoO}_{4}\right)$ at the experimental $\mathrm{pH}$ of 6 for $10^{-4} \mathrm{M} \mathrm{Pb}^{2+}$ and $\mathrm{pH}$ of 7 for $10^{-6}$ and $10^{-7} \mathrm{M} \mathrm{Pb}^{2+}$. Conversely, the precipitation of cerussite $\left(\mathrm{PbCO}_{3}\right)$, hydrocerussite $\left(\mathrm{Pb}\left(\mathrm{CO}_{3}\right)_{2}(\mathrm{OH})_{2}\right)$, lead hydroxide $\left(\mathrm{Pb}(\mathrm{OH})_{2}\right)$, and litharge $(\mathrm{PbO})$ are not thermodynamically possible under these conditions. However, it is important to note that a positive saturation index does not guarantee the precipitation of a given mineral phase, since kinetic factors such as limitation of nucleation processes have to be also considered. The predicted precipitation of wulfenite in the mineralization medium was nonetheless confirmed by SEM observations of the precipitates obtained in the abiotic experiment performed using $10^{-6} \mathrm{M} \mathrm{Pb}^{2+}$ (Supplementary data Fig. A1). There, $1 \mu \mathrm{m}$ octahedral wulfenite crystals were observed after $24 \mathrm{~h}$ of lead exposure, with EDXS chemical identification confirming $\mathrm{Pb}$ and Mo colocalization.

Similar calculations were conducted for the $10^{-2} \mathrm{M} \mathrm{NaNO}_{3}$ solutions supplemented with lead at $10^{-4} \mathrm{M}$ and $10^{-6} \mathrm{M}$ (Figs. 1d-e). Although saturation indexes can be close to 0 for $\mathrm{Pb}(\mathrm{OH})_{2}$ and $\mathrm{PbCO}_{3}$ at both $\mathrm{pH} 7$ and 6, cerussite precipitates were observed by SEM at the alumina surface exposed during $24 \mathrm{~h}$ to lead concentrations of $10^{-4} \mathrm{M}$ in $10^{-2} \mathrm{M} \mathrm{NaNO}_{3}$ solutions, but no at $10^{-6} \mathrm{M}$ (data not shown). 
The S. oneidensis MR-1 biofilms were composed of aggregated structures of variable density, with total thickness varying from 0.6 to $1.1 \mu \mathrm{m}$, as shown by FIB-SEM (Fig. 2b). While Wang et al. (2016) used the same experimental conditions to produce S. oneidensis MR1 biofilms, these authors observed under hydrous conditions a biofilm thickness in the range 6 to $20 \mu \mathrm{m}$ (instead of $\sim 1 \mu \mathrm{m}$ in the present case for dry biofilms). Shrinking of the hydrated polymer network may have led to a lowering in biofilm thickness during drying. However we were still able to observe a well-defined porosity and organic polymer connecting one bacteria to the other and to the alumina substrate. Few studies used FIB-SEM to study biofilms (Reith et al., 2010; Toner et al., 2009) and none of them managed to investigate their thickness and preserve their fragile organic structure and porosity. Here, the overall structure of the obtained biofilm was porous and showed multiple layers of bacteria interconnected by EPS, in agreement with observations from Flemming and Wingender (2010). The observed porosity was very heterogeneous depending on the bacterial cell density, and no significant differences were observed between biofilms exposed to mineralization media or to $\mathrm{NaNO}_{3}$ solutions. The observed porous cavities vary continuously in shape and size, from 300 nm (Figs. 2 a,b and 3a) to $50 \mathrm{~nm}$ in diameter (Fig. $3 b$, zone 2).

Figure 4 presents C 1 s core levels obtained by XPS on biofilms exposed during $1 \mathrm{~h}$ at a lead concentration of $10^{-4} \mathrm{M}$. The $\mathrm{C} 1 \mathrm{~s}$ peak fitting was performed using the same binding energy assignments as in Rouxhet et al. (1994). Three contributions were considered: the first peak at the lowest binding energy of $285 \pm 0.1 \mathrm{eV}$ was assigned to carbon only bonded to $\mathrm{C}$ or $\mathrm{H}$; the second peak at $286.6 \pm 0.1 \mathrm{eV}$ was attributed to carbon in $\mathrm{C}-\mathrm{N}$ and $\mathrm{C}-\mathrm{O}$ single bonds; the third peak at $288.7 \pm 0.1 \mathrm{eV}$ was attributed to carbon in carbonyl or carboxyl functional groups. The Al $2 p$ peak (not shown) was well fitted with a component at $74.9 \pm 0.1 \mathrm{eV}$ corresponding to $\mathrm{Al}$ in $\alpha-\mathrm{Al}_{2} \mathrm{O}_{3}$. The $\mathrm{O} 1 \mathrm{~s}$ peak was well fitted with a component at $531.4 \pm$ 
$0.1 \mathrm{eV}$ corresponding to oxygen in oxides and organic compounds. The P $2 p$ peak was well fitted with a component at $134.5 \pm 0.1 \mathrm{eV}$ associated with phosphates. The $\mathrm{N} 1$ s peak was well fitted with a component at $400 \pm 0.1 \mathrm{eV}$ corresponding to nitrogen in protein peptide bonds. It is representative of cell proteins and extracellular proteins secreted by bacteria, thus constituting a good indicator of biofilm material, as carbon is. Measured relative elemental abundances $d_{i}$ given by XPS for biofilms exposed to lead at different concentrations and exposure times are reported in Table 2.

Given the extremely small depth probed by XPS analysis (i.e., $10 \mathrm{~nm}$ ), these relative elemental abundances $d_{N}$ served to evaluate the extent $\theta$ of biofilm covering the $\alpha-\mathrm{Al}_{2} \mathrm{O}_{3}$ substrate using the following equations:

$$
\begin{aligned}
& I_{N}=k \sigma_{N} \lambda_{N}^{\text {biof }} D_{N}^{\text {biof }} T_{N}\left(1-\exp \left(\frac{d_{N}}{\lambda_{N}^{b i o f} \cdot \sin q}\right)\right) \\
& I_{A l}=k \sigma_{A l} \lambda_{A l}^{\text {alum }} D_{A l}^{\text {alum }} T_{A l}\left(1-\exp \left(\frac{d_{A l}}{\lambda_{A l}^{\text {alum }} \cdot \sin q}\right)\right) \\
& \theta=\frac{I_{N}}{I_{A l}}
\end{aligned}
$$

where $\lambda_{N}^{b i o f}$ is the attenuation length of photoelectrons from element $N$ in the biofilm (biof), $\lambda_{A l}^{a l u m}$ is the attenuation length of $\mathrm{Al}$ photoelectrons in the alumina substrate (alum), $I_{A l}$ and $I_{N}$ are the intensity of $\mathrm{Al}$ in alumina and intensity of $N$ in biofilm; $q$ is the take-off angle of the photoelectrons with respect to the surface plane $\left(q=90^{\circ}\right.$ in this work), $k$ is an apparatus constant, $D_{N}^{\text {biof }}$ is the atomic concentration of $N$ in the biofilm, $D_{A l}^{\text {alum }}$ is the atomic concentration of $\mathrm{Al}$ in the alumina substrate. $T_{x}$ and $\sigma_{x}$ are the transmission factor and photoionisation cross section of the photoelectrons emitted from $x$, respectively (Rouxhet et al., 1994) and $d$ is the measured relative abundance of $N$ and Al. The biofilm composition was approximated as $\mathrm{C}_{8} \mathrm{H}_{9} \mathrm{O}_{2} \mathrm{~N}$.

On the basis of this calculation, the biofilm coverage was evaluated at $65 \pm 5 \%$ of the surface for the experiment carried out with $10^{-4} \mathrm{M} \mathrm{Pb}^{2+}$ in the mineralization medium for $1 \mathrm{~h}$ 
exposure, $73 \pm 5 \%$ with $10^{-4} \mathrm{M} \mathrm{Pb}^{2+}$ for $24 \mathrm{~h}$ exposure, and $72 \pm 5 \%$ with $10^{-6} \mathrm{M} \mathrm{Pb}^{2+}$ for $24 \mathrm{~h}$ exposure, respectively. The very small differences in coverage between these three conditions suggest that $\mathrm{Pb}$ exposure did not significantly impact the overall biofilm coverage for $24 \mathrm{~h}$ exposure, in agreement with direct CLSM observations on similar systems reported by Wang et al. (2016).

\subsection{Lead accumulation dynamics within the biofilm in the mineralization medium}

Sample preparation through dehydration and critical point drying may have induced biased precipitation of minerals. However the ethanol fixation steps likely allowed most of the residual lead to be removed from the preparation, hence preventing subsequent precipitation during drying. Importantly, in any case it would have changed the mineralization gradient.

\subsubsection{Pb distribution: precipitation hotspots}

SEM and TEM micrographs of a $S$. oneidensis MR-1 biofilm exposed to the mineralization medium at $10^{-6} \mathrm{M} \mathrm{Pb}^{2+}$ for $24 \mathrm{~h}$ are presented in Figs. 5a-b. Small bright patches (see red arrows) of few micrometers are sparsely observed. They are colocalized with biofilm-enclosed individual bacterial cells (highlighted by green arrows) or EPS. Associated EDXS spectra (Fig. 5d) show that they are composed of $\mathrm{Pb}, \mathrm{P}$ and to a lesser extent, $\mathrm{Cl}$. These $\mathrm{Pb}$ - and P-bearing hotspots indicate that lead precipitation was highly heterogeneous within the biofilm, as also observed for the other used $\mathrm{Pb}$ concentrations and exposure times.

\subsubsection{Changes in Pb speciation over time}

After deconvolution, the $\mathrm{Pb} 4 \mathrm{f}_{7 / 2}$ contribution in XPS spectra collected on biofilms after $1 \mathrm{~h}$ and $24 \mathrm{~h}$ exposure to the mineralization medium at lead concentrations of $10^{-4}$ and $10^{-6} \mathrm{M}$ was resolved with a band centered at $139.2 \pm 0.1 \mathrm{eV}$, close to the value of $138.9 \mathrm{eV}$ 
reported for pyromorphite (Eighmy et al., 1998). This slight shift in energy was likely due to the flood gun used for charge compensation since the biofilm surface is not electrically conductive, and this effect is probably large enough to prevent reliable assignment. The presence of pyromorphite was confirmed at the micrometer scale for different exposure times (i.e., $1 \mathrm{~h}$ and $24 \mathrm{~h}$ ) by TEM-EDXS chemical identification, indicating systematic colocalization of $\mathrm{Pb}$ and $\mathrm{P}$ in these minerals, while Mo was never detected in the precipitates obtained during short-duration experiments (Fig. 5d). The first pyromorphite crystals observed after $1 \mathrm{~h}$ and $24 \mathrm{~h}$ of $10^{-6} \mathrm{M}$ lead exposure in the mineralization medium exhibited a sub-nanometric size (e.g., Fig. 3b). The pH of the medium did not significantly change in the meantime (from $7.0 \pm 0.1$ to $6.9 \pm 0.1$ ). As noted previously, the precipitates were found to be closely associated with bacteria cells and EPS, as also observed in the experiments performed with $10^{-4} \mathrm{M} \mathrm{Pb}^{2+}$ in the $10^{-2} \mathrm{M} \mathrm{NaNO}_{3}$ solution for $1 \mathrm{~h}$ (Fig. 5c). Conversely, after 7 days of exposure (168 h) to $\mathrm{Pb}^{2+}$ at $10^{-6} \mathrm{M}$ and $10^{-7} \mathrm{M}$ in the mineralization medium, regular octahedra of approximately $3 \mu \mathrm{m}$ in edge length were systematically observed (Fig. 6; yellow dashed arrows). Noticeably, these precipitates were covered by bacteria and by organic material (Figs. $6 \mathrm{a}$ and $\mathrm{d})$. Bacteria entombed in the precipitates were also commonly observed suggesting that the minerals precipitated in situ in the biofilm and do not correspond to crystals grown in solution and then sedimented over the biofilm. SAED were acquired on these precipitates, and the following parameters were extracted from the diffraction pattern: $a=2.71 \AA$ for (200), $b=$ $2.36 \AA$ for $(114)$ and $\alpha=116^{\circ}$. They correspond to wulfenite according to the ICDD reference 00-044-1486 (Fig. 6e). The presence of wulfenite was confirmed by Raman spectroscopy (Supplementary data Fig. A2). In addition, in these long-duration experiments, pyromorphite remained detectable at some specific biofilm locations (Fig. 6b).

\subsection{Evolution of lead and molybdenum concentrations in the supernatant during biofilm exposure to $\mathrm{Pb}^{2+}$}


For the biotic experiments, the temporal evolution over 7 days of $\mathrm{Pb}$ and Mo total concentrations in the supernatant is reported in Fig. 7. For the mineralization medium supplemented with $10^{-7} \mathrm{M} \mathrm{Pb}^{2+}$, lead concentrations in the supernatant remained stable during the whole time period of $168 \mathrm{~h}$. On the contrary, at $10^{-6} \mathrm{M} \mathrm{Pb}^{2+}$, lead concentrations remained constant during the first 16 hours and then decreased to reach a final concentration of approximately $2 \cdot 10^{-7} \mathrm{M}$ after $168 \mathrm{~h}$ of lead exposure. This decrease in supernatant $\mathrm{Pb}$ concentrations suggests an accumulation of lead in the biofilm or at the alumina surface, either as solid precipitates or by sorption of $\mathrm{Pb}^{2+}$.

Experimental concentrations of total dissolved $\mathrm{Pb}^{2+}$ and $\mathrm{MoO}_{4}{ }^{2-}$ in the supernatant were compared to $\mathrm{Pb}$ and Mo concentrations predicted using Visual MINTEQ v3.0 by considering either $\mathrm{Pb}$ precipitation or sorption (Fig. 7). Initial $\mathrm{MoO}_{4}{ }^{2-}$ concentrations were set, as in the mineralization medium, at $3.9 \cdot 10^{-6} \mathrm{M}$ and $\mathrm{Pb}^{2+}$ concentrations at either $10^{-6} \mathrm{M}$ (blue model lines in Fig. 7) or $10^{-7} \mathrm{M}$ (red model lines in Fig. 7). Atmospheric $\mathrm{CO}_{2}$ partial pressure $\left(\mathrm{pCO}_{2}\right)$ was set at 0.00038 atm to include an atmospheric contribution to the carbonate system. Calculations were run at $\mathrm{pH} 6.0,6.5,7.0$, as the initial $\mathrm{pH}$ of the mineralization medium was adjusted to 7.0 for these $\mathrm{Pb}^{2+}$ concentrations but $\mathrm{pH}$ down to 5.9 were also reported within biofilms (Hunter and Beveridge, 2005). Thermodynamic parameters for lead adsorption on $S$. oneidensis MR-1 biofilms have been determined by Ha et al. (2010). These authors have established the thermodynamic parameters for two distinct sites binding $\mathrm{Pb}^{2+}$ within the biofilm, i.e., carboxyl and phosphoryl sites. Values of $\log K_{\mathrm{s}}=4.1$ and $\log \mathrm{K}_{\mathrm{s}}=4.2$ were considered for lead adsorption onto deprotonated carboxyl and deprotonated phosphoryl functional groups, respectively (Ha et al., 2010). Their respective abundance in S. oneidensis MR-1 biofilm was estimated at $126 \mathrm{mM} \cdot \mathrm{g}_{\text {cell }}{ }^{-1}$ and $37 \mathrm{mM} \cdot \mathrm{g}_{\text {cell }}{ }^{-1}$ (Ha et al., 2010). In the calculations, although phosphate ions were absent in the mineralization medium, phosphate concentrations were allowed to vary between $1.5 \cdot 10^{-3}$ and $3 \cdot 10^{-5} \mathrm{M}$ to account for the 
precipitation of pyromorphite observed in the experiments. This latter range of phosphate concentrations is the one allowing the precipitation of both wulfenite and pyromorphite, as observed in the experiments in which bacteria are the unique reservoir of phosphorus. The used solubility product for pyromorphite was $\log \mathrm{K}_{\mathrm{s}}=-80.4$, assumed equal to that of chloropyromorphite (Xie and Giammar, 2007), while $\log \mathrm{K}_{\mathrm{s}}$ was taken equal to -15.62 for wulfenite. The chlorinated form of pyromorphite was preferred since it is widespread in $\mathrm{Pb}$ rich environments, and it corresponds to the most stable form (Rhee et al., 2012, 2014). In addition, a chlorine signal was detected in the EDXS spectra collected in the pyromorphite mineral precipitated in S. oneidensis biofilms (Fig. 5d). Equilibrium between free lead and chloropyromorphite was considered as (Eq. (5)):

$\mathrm{Pb}_{5}\left(\mathrm{PO}_{4}\right)_{3} \mathrm{Cl}(\mathrm{s})=5 \mathrm{~Pb}^{2+}+3 \mathrm{PO}_{4}{ }^{3-}+\mathrm{Cl}^{-}$

$\log \mathrm{K}_{\mathrm{spl}}=\left\{\mathrm{Pb}^{2+}\right\}^{5} \cdot\left\{\mathrm{PO}_{4}{ }^{3-}\right\}^{3} \cdot\left\{\mathrm{Cl}^{-}\right\}$

and equilibrium between free lead and wulfenite as (Eq. (7)):

$\mathrm{PbMoO}_{4}(\mathrm{~s})=\mathrm{Pb}^{2+}+\mathrm{MoO}_{4}^{2-}$

$\log \mathrm{K}_{\mathrm{sp} 2}=\left\{\mathrm{Pb}^{2+}\right\} .\left\{\mathrm{MoO}_{4}{ }^{2-}\right\}$

In Figure 7a, results correspond to an average of lead and molybdenum concentrations obtained for thermodynamic calculations at $\mathrm{pH} 6.0,6.5$ and 7.0 considering phosphates concentrations ranging from $1.5 \cdot 10^{-3}$ to $3 \cdot 10^{-5} \mathrm{M}$. For these ranges of $\mathrm{pH}$ and phosphate concentrations, variations are small and uncertainties (from standard deviation) are within the symbols.

For an initial lead concentration of $10^{-6} \mathrm{M}$, the supernatant concentrations in lead are first roughly following the thermodynamic predictions for lead sorption onto the biofilm functional groups established by preventing precipitation to occur (blue dashed line on Fig. 7a). Once $\mathrm{Pb}$ concentrations decreased after $16 \mathrm{~h}$ of biofilm exposure, they did not fully reach the predicted lead concentrations obtained when wulfenite and pyromorphite precipitate at thermodynamic equilibrium (blue dotted line on Fig. 7a). The lag period preceding the drop in 
$\mathrm{Pb}^{2+}$ in the mineralization medium may be related to the dynamics of lead mineralization since evidences of the presence of pyromorphite are visible after $1 \mathrm{~h}$ of lead exposure. This drop may also be driven by limiting phosphate concentrations that are able to consume $\mathrm{Pb}^{2+}$ in the medium and therefore to decrease its concentration once available at sufficient concentration for the supersaturation with respect to pyromorphite to be reached. For an initial lead concentration of $10^{-7} \mathrm{M}$, the supernatant concentrations in lead strictly follow the thermodynamic predictions for lead sorption onto the biofilm (red dashed line on Fig. 7a) even after $16 \mathrm{~h}$ of biofilm exposure to $\mathrm{Pb}^{2+}$.

Measured $\mathrm{MoO}_{4}{ }^{2-}$ concentrations remained roughly stable during the same time period whatever the initial concentration of $\mathrm{Pb}^{2+}$. Measured concentrations of $\mathrm{MoO}_{4}{ }^{2-}$ in the mineralization medium are in the range of the computed concentrations of $\mathrm{MoO}_{4}{ }^{2-}$ obtained when both sorption and precipitation are allowed (i.e., $3.9 \cdot 10^{-6} \pm 1.3 \cdot 10^{-6} \mathrm{M}$ ).

\subsection{Insight from short time experiments performed in the lead amended $\mathrm{NaNO}_{3}$ solution}

\subsubsection{Precipitates' location in the bacterial biofilms}

When exposed to $10^{-4} \mathrm{M} \mathrm{Pb}^{2+}$ for $24 \mathrm{~h}$ in the $\mathrm{NaNO}_{3}$ solution, biofilms were covered by a crust of spherical globules of around $20 \mathrm{~nm}$ in diameter, mainly overlying the organic structure (Fig. 3a, zone 1), but also present in the whole biofilm porosity (Fig. 3a, zone 2). At shorter exposure times (i.e., $1 \mathrm{~h})$ or lower lead concentrations $\left(10^{-6} \mathrm{M} \mathrm{Pb}\right.$ for $\left.24 \mathrm{~h}\right)$, the precipitates formed small wire-like clusters, specifically localized close to the bacterial cells, but usually not directly on their surfaces (Figs. 3b and 5c). For these short exposure times and low lead concentrations, precipitation occurred mostly at the accessible EPS interface between the $\mathrm{Pb}^{2+}$-bearing overlying solution and the biofilm (Fig. 3b, zone 1), while the dense network of EPS located closer to the mineral substrate (i.e., the farthest for the solutionbiofilm interface) do not host any precipitate (Fig. 3b zone 2). Accordingly, at low $\mathrm{Pb}^{2+}$ 
concentrations or for short exposure times, precipitation was heterogeneous, mainly occurring in the top layers of the biofilm, hence suggesting an important kinetic control arising from the competition between lead-bearing mineral precipitation and lead migration through the biofilm.

\subsubsection{Identification of the precipitates}

After $24 \mathrm{~h}$ of $\mathrm{Pb}^{2+}$ exposure at $10^{-4} \mathrm{M}$ in the lead-amended $\mathrm{NaNO}_{3}$ solution, two types of precipitates, often closely associated, were observed by TEM (Fig. 8). The first type (Fig. 8a zone 1) consisted in polycrystalline and porous square phases of hundreds of nanometers in length. SAED collected on this precipitate attested for the presence of cerussite $\left(\mathrm{PbCO}_{3}\right)$ with its characteristic (112) and (-221) crystallographic planes (ICDD 00-05-0417) (Fig. 8d). The elemental compositions obtained by EDXS revealed the presence of $\mathrm{Pb}$ while $\mathrm{P}$ was absent, thus confirming the presence of cerussite. The weak P peak observed in the EDXS spectra is due to phosphorus contained in the organic material. Carbon was not considered since amorphous carbon was deposited on the samples to avoid any charge effects during SEM observations and the carbon signal can also arise from the carbon coated copper TEM grid.

The second type of precipitate consisted in $20 \mathrm{~nm}$ spherical crystals (Fig. 8a zone 2 and Fig. 8b zones 3-4). They were identified as pyromorphite, based on its characteristic (200), (300) and (112) crystallographic planes shown by SAED (ICDD 00-24-0586) (Fig. 8e). The elemental compositions obtained by EDXS revealed the joint presence of $\mathrm{Pb}$ and $\mathrm{P}$, thus confirming the presence of pyromorphite.

Interestingly, cerussite and pyromorphite are found in close vicinity, cerussite being systematically identified when pyromorphite is present (Figs. 8a and b). 


\section{Discussion}

Given the general aspect of the biofilms and their surface composition derived from XPS measurements (Table 2), it can be considered that the biofilms used in the different experiments are similar enough to be compared one with the other.

In the mineralization medium, wulfenite precipitates were detected after $24 \mathrm{~h}$ of lead exposure at $10^{-6} \mathrm{M}$ in the abiotic system (Supplementary data Fig. A1), while this phase was only observed after one week of lead exposure at a similar lead concentration in the presence of S. oneidensis MR-1 biofilms (Fig. 6). Differences in dynamics of lead precipitation between the biotic and abiotic systems were further confirmed by the mobilization of lead in the form of pyromorphite after one day of biofilm exposure in the biotic experiments (Figs. 3 and 5).

\subsection{Biologically induced precipitation of lead phosphates}

\subsubsection{Lead sequestration into pyromorphite biominerals}

Pyromorphite associated with EPS in bacterial biofilms was already reported in several experimental and natural systems. For instance, this mineral phase was observed in laboratory experiments involving a single-layer bacterial biofilm of Burkholderia cepacia exposed to lead (Templeton et al., 2001). Based on literature reports dealing with lead-rich environments, it appears that pyromorphite is frequently invoked as an extremely stable phase in which lead is likely to be sequestered, as shown for environmental fungal biofilms grown on metallic Pb (Liang et al., 2016; Rhee et al., 2012, 2014), and in soil fungi (Liang et al., 2016). Here, biomineralization of pyromorphite occurred in S. oneidensis MR-1 biofilm from one hour of lead exposure at $10^{-4} \mathrm{M}$ in experiments performed in $\mathrm{NaNO}_{3}$ solution (Fig. 5c) and at $10^{-4} \mathrm{M}$ and $10^{-6} \mathrm{M}$ in experiments performed in the mineralization medium (Fig. 3b). In 
both media, precipitation occured mostly away from the cells in the organic strands generated by the bacterial cells (Figs.3b and 5c) as previously observed by Chan et al. (2009) and Miot et al. (2009) during experiments involving iron, and in the Carnoules acid mine drainage (Benzerara et al., 2011). However, in the present study, precipitation was also observed close to the bacterial cell membranes (Fig. 8c) but this could potentially result from EPS shrinking or from the presence of EPS at the cell surface.

Mineralization of phosphates on biological material has been previously discussed by several authors (Cosmidis et al., 2014; Weiner and Dove, 2003) and similar mechanisms can be considered here to describe the process of pyromorphite precipitation on bacterial cells and adjacent EPS. The negatively-charged functional groups (mainly as carboxyl and phosphoryl moieties) present on bacteria and EPS allow adsorption of soluble metallic cations such as $\mathrm{Pb}^{2+}$ on the organic material (Beveridge and Murray, 1980; Fein et al., 2001; Konhauser, 1998; Templeton et al., 2003). Accumulation of $\mathrm{Pb}^{2+}$ at the surface and within the porosity of biofilm can favor the nucleation of lead minerals. By comparing the measured concentrations of total dissolved $\mathrm{Pb}^{2+}$ and $\mathrm{MoO}_{4}^{2-}$ in the supernatant to concentrations obtained when modeling either their sorption or the simultaneous precipitation of wulfenite and pyromorphite within the bacterial biofilm, it shows that sorption on the biofilm is slightly underestimated in thermodynamic calculations. Indeed, there should be a significant contribution of the interaction between the lead ions and the alumina substrate as suggested on clean, uncoated alumina surfaces (Templeton et al., 2003). Measured concentrations of $\mathrm{Pb}^{2+}$ did not fully reached concentrations expected when considering simultaneous precipitation of wulfenite and pyromorphite at thermodynamic equilibrium within the modeled biofilm. This gap suggests an additional control of the biofilm on the biomineralization process, likely related to mineral dissolution via, for example, the release of organic acids (Topolska et al., 2014). Additionally, the nanometric size of the lead particles likely had an impact on their reactivity and therefore on their respective $\mathrm{K}_{\mathrm{sp}}$ values. They are 
indeed much more reactive than their relative bulk material. This implies a different thermodynamic description of the experimental system that was however not considered here because the size impact on $\mathrm{K}_{\mathrm{sp}}$ values is unknown for these lead-bearing minerals. In Mo-free systems, observed phenomena were quite similar except that cerussite, instead of wulfenite, is the thermodynamically-stable mineral. In all cases, an increase of phosphate ions is needed to exceed the critical saturation state and allow the precipitation of pyromorphite (Eq. (5)).

\subsubsection{Biofilm as a reservoir of phosphates}

The absence of phosphorus in the mineralization medium should have prevented any pyromorphite precipitation as predicted by thermodynamic modeling (Fig. 1) and verified in the corresponding abiotic controls. To explain the precipitation of a phosphate-bearing mineral phase competing with wulfenite or cerussite, the presence of significant amounts of free phosphate ions in the biofilm thickness is required. Wu et al. (2006) suggested that bacterial metabolic activity favors the formation of pyromorphite compared to bacteria free systems because of their ability to extract free phosphate from cellular phosphates and polyphosphates. The increase in free inorganic phosphate concentration around bacteria cells is frequently correlated to the release of phosphates associated with microbial phosphatase activity (Benzerara et al., 2011; Cosmidis et al., 2015). Metabolically active bacterial biofilms are able to host an important phosphatase activity as highlighted in particular in river biofilms, stream biofilms and marine aggregates (Wingender and Jaeger, 2002; Flemming and Wingender, 2010). This is likely to trigger a local increase in free phosphate ions which is required to exceed the critical saturation state and to cause pyromorphite precipitation as already shown for other types of phosphate minerals (Cosmidis et al., 2014, 2015). If phosphate likely originates from the metabolically active bacterial biofilms, chloride ions incorporated into pyromorphite likely come from the salts added to the mineralization medium nonetheless at concentration lower than the ones encountered in most of the natural 
rivers such as the Seine river with an average $\mathrm{Cl}$ concentration of $0.47 \mathrm{mM}$ (Roy et al., 1999); the hydroxide is thermodynamically stable at $\mathrm{pH} 7$ in the mineralization medium. Overall, by promoting the release of free phosphate ions, the biofilm strongly impacts the precipitation kinetics and stability of minerals such as pyromorphite, even for experimental conditions nominally free of phosphates. Accordingly, in order to understand the dynamics of $\mathrm{Pb}$-bearing minerals at the solution/biofilm interface, some key parameters that need to be considered, in addition to local lead concentrations, are the phosphate and $\mathrm{pH}$ distributions in the biofilm thickness.

\subsection{Evidences of diffusion-controlled reactivity in the biofilm}

The distribution of pyromorphite precipitates within the biofilm thickness gives an idea of the efficiency of lead diffusion through the porous organic and metabolically active structure (Fig. 3). Since precipitation can only occur once the critical saturation state is reached, the location of pyromorphite formation is a proxy for local supersaturation in lead. For the first time, the locations of precipitates in the thickness of a biofilm were resolved by electron microscopy using FIB-milled cross-sections. In the experiments performed in $\mathrm{NaNO}_{3}$ solution supplemented with $10^{-4} \mathrm{M} \mathrm{Pb}^{2+}$, the precipitation occurred in the whole biofilm thickness after $24 \mathrm{~h}$ of lead exposure (Fig. 3a), hence attesting for an efficient migration of lead from the biofilm surface towards the high-affinity aluminum substrate at a rate comparable to the one estimated by Wang et al. (2016) for a similar system. At lower lead concentrations (i.e., $10^{-6} \mathrm{M}$ ) but similar exposure times in both the mineralization medium and the $\mathrm{NaNO}_{3}$ solution, a smaller quantity of lead has migrated through the whole organic structure and the system favored nucleation sites at the upper biofilm surface far from the alumina substrate (Fig. 3b). Lead penetration within the biofilm was thus strongly limited due to surficial precipitation, indicative of supersaturated environments already met in close 
vicinity of the biofilm surface. This evidence of supersaturated conditions occurring close to the biofilm/solution interface is in agreement with the observations of pyromorphite precipitation in Burkholderia cepacia biofilms that developed as single layered colonies of limited thickness (Templeton et al., 2003). On the contrary, experiments using an alumina substrate coated with a film of polyacrylic acid aiming at mimicking carboxyl functional groups as fixation sites indicated free lead diffusion (Yoon et al., 2005). This highlights the critical role of local extracellular phosphate concentrations in microenvironments that impose a strong control on secondary mineral formation and of $\mathrm{Pb}$ transport dynamics at the mineral/biofilm/solution interface.

\subsection{Transient phosphate mineral phases}

In both the mineralization medium and the $\mathrm{NaNO}_{3}$ solution, two types of precipitates were characterized by SAED and EDXS. In the mineralization medium, the predicted thermodynamically-stable phase wulfenite was not the first mineral to precipitate. As discussed previously, the likely hydrolysis of organic phosphate resulting in accumulations of phosphate ions within the biofilm led first to the precipitation of pyromorphite within few hours. Then, as time went by, wulfenite became the main Pb-bearing solid phase in the biofilm after 7 days of lead exposure (Fig. 6). Interestingly, the late formation of wulfenite is likely correlated to a strong decrease in dissolved $\mathrm{Pb}^{2+}$ in the supernatant (Fig. 7). The relative rates of precipitation of pyromorphite and wulfenite could be at the origin of this sequential behaviour. However, abiotic experiments in the mineralization medium show an important occurrence of wulfenite after only 24 hours (Supplementary data Fig. A1), demonstrating a relatively fast precipitation of this phase. For the biotic experiments, the sole presence of pyromorphite is detected after 24 hours of lead exposure without any evidence of wulfenite precipitation for all the samples (Fig. 5). It is thus unlikely that the relative difference in rate 
of precipitation for these two minerals supports alone the observed data at 24 hours. In addition, one could consider that the delayed precipitation of wulfenite could be caused by the faster formation of pyromorphite. In that case, free $\mathrm{Pb}^{2+}$ in the biofilm would be initially consumed by pyromorphite precipitation until exhaustion of the extracellular phosphate stock, followed by wulfenite precipitation using the remaining $\mathrm{Pb}^{2+}$ that continuously accumulates in the biofilm. However, the observed decrease in the quantity of pyromorphite precipitates between 24 hours and 7 days discards this scenario. Another hypothesis explaining this sequential precipitation is that phosphate, as a nutrient, was consumed by bacteria, leading to pyromorphite partial dissolution, and the concomitant release of lead in biofilm microenvironments followed by subsequent precipitation of the thermodynamically-stable wulfenite. There is however no direct evidence for pyromorphite dissolution. Evaluating the thermodynamic driving force for this dissolution/re-precipitation process is in addition impossible because the local phosphate concentration is not available. Nonetheless, Debela et al. (2010) and Topolska et al. (2014) suggested that the release of metabolic organic acids was responsible for the possible dissolution of phosphate minerals. Thus, the evolution from pyromorphite to wulfenite as the main $\mathrm{Pb}$-bearing mineral phase in the investigated system is likely to result mainly from this biotic control, combined to a lesser extent to kinetic limitations during precipitation.

The presence of two closely-associated mineral phases was also highlighted in the experiment performed in $\mathrm{NaNO}_{3}$ solution. Aggregated pyromorphite nanoparticles were found over EPS within the biofilm after 1 hour of lead exposure (Fig. 4c). Clusters of $\sim 300$ nm porous cerussite crystals occurred close to pyromorphite after $24 \mathrm{~h}$ of lead exposure (Fig. 8). The precipitation of this mineral phase probably resulted from local increase in dissolved inorganic carbon produced during bacterial respiration since $S$. oneidensis MR-1 is able to oxidize lactate, the carbon source used in the experiment, to form $\mathrm{CO}_{2}$ under aerobic conditions (Pinchuk et al., 2010, 2011). Nevertheless, the close co-occurrence of cerussite and 
pyromorphite (Fig. 8b) suggests a relationship between these two phases. Three processes are detailed in the literature to explain the formation of bio-precipitates. The most classical mechanism is the growth of a nucleus by addition of matter, atoms by atoms, to an inorganic or organic template (De Yoreo and Vekilov, 2003). The second one is the dissolution of unstable phases (either small particles with high surface energy or metastable polymorphs) and re-precipitation following Ostwald ripening that causes coarsening of particles. In this process, dissolution could has been triggered by the fact that larger mineral structures (such as wulfenite or cerussite) are energetically favored compared to nano-sized mineral (such as pyromorphite, corresponding on the present case to particles of about 20-30 nm in diameter). Small particles are of higher energy. They are hence more reactive and tend to dissolve. Free lead released in solution may redeposit onto the surface of bigger particles and react with Mo to form wulfenite. The third mechanism is aggregation bonding (Banfield et al., 2000; Penn and Banfield, 1998) due to short-range interactions between adjacent surfaces. In order to remove the surface energy associated with unsatisfied bonds, particles rotate within aggregates up to complete elimination of the mineral-air or mineral-fluid interface. This phenomenon leads to oriented nanoparticles chains and sheets during natural biomineralization. Only the second mechanism of dissolution/re-precipitation can explain a phase evolution with chemical change, as the components are free again to reinsert into a new crystallographic configuration. Additionally, the close vicinity of both pyromorphite and cerussite tends to support possible dissolution/re-precipitation.

\section{Conclusion}

Unraveling the role of biofilms in biomineralization processes is still at its infancy and little is known in particular on the role of micro-environments encountered in biofilms and of their components on the nature of minerals that are formed in such systems. Here we showed 
that although we set experimental conditions favoring the precipitation of two distinct thermodynamically-stable mineral phases (both conditions excluded pyromorphite and favored instead cerussite or wulfenite), the first mineral phases to form in biofilms in leadexposed systems were heterogeneously distributed pyromorphite nanoparticles mostly associated to EPS that could have acted as nucleation sites. Other thermodynamically-stable mineral phases such as wulfenite (if Mo is present) or cerussite can form at slightly longer timescales depending on the presence of other chemical species (e.g., carbonate ions). Although association of pyromorphite and wulfenite were already found in lead mines (Fransolet et al., 1978), the relationship between pyromorphite and these other mineral phases is not yet well established in the environment and has to be further studied. Nevertheless, the spatial relationship demonstrated here between the $\mathrm{Pb}$-bearing minerals suggests mechanisms of dissolution/re-precipitation. We also highlighted an important control of the metabolic activity of bacteria that can modify the local $\mathrm{pH}$ and likely supplied extracellular free phosphate and carbonate species. In addition, porosity/permeability and metal, protons, carbonate and phosphate diffusion properties within the biofilm are also key factors to understand mineralization mechanisms in bacterial biofilms since they concur to the formation of microenvironments within the biofilm. Given their central importance for the chemical transfers of elements from the aqueous phase to the biofilm nucleation sites, a better characterization of the physico-chemical properties of microenvironments in biofilms is required in order to fully understand the complex mechanisms occurring during metal(loid)s interactions with bacterial biofilms.

\section{Acknowledgments}

We gratefully thank Stephan Borensztajn for assistance during SEM experiment and FIB milling. Part of this work was supported by the IPGP multidisciplinary program PARI 
and by Région Ile-de-France SESAME grant No. 12015908. We also acknowledge grant Emergence(s) from the ville de Paris and the PIREN Seine research program.

\section{Appendix A. Supplementary data}

Supplementary data are attached to this article.

\section{References}

Banfield, J.F., Welch, S.A., Zhang, H., Ebert, T.T., Penn, R.L., 2000. Aggregation-based crystal growth and microstructure development in natural iron oxyhydroxide biomineralization products. Science $289,751-754$.

Benzerara, K., Miot, J., Morin, G., Ona-Nguema, G., Skouri-Panet, F., Férard, C., 2011. Significance, mechanisms and environmental implications of microbial biomineralization. C. R. Geosci. 343, 160-167. https://doi.org/10.1016/j.crte.2010.09.002

Beveridge, T.J., Murray, R.G., 1980. Sites of metal deposition in the cell wall of Bacillus subtilis. J. Bacteriol. 141, 876-887.

Blanc, P., Lassin, A., Piantone, P., Azaroual, M., Jacquemet, N., Fabbri, A., Gaucher, E.C., 2012. Thermoddem: A geochemical database focused on low temperature water/rock interactions and waste materials. Appl. Geochem. 27, 2107-2116. https://doi.org/10.1016/j.apgeochem.2012.06.002

Brown, G.E., Calas, G., 2011. Environmental mineralogy - Understanding element behavior in ecosystems. C. R. Geosci. 343, 90-112. https://doi.org/10.1016/j.crte.2010.12.005

Brown, Jr., G.E., Calas, G., 2012. Mineral-aqueous solution interfaces and their impact on the environment. Geochem. Perspect. 483-742. https://doi.org/10.7185/geochempersp.1.4 
Chan, C.S., Fakra, S.C., Edwards, D.C., Emerson, D., Banfield, J.F., 2009. Iron oxyhydroxide mineralization on microbial extracellular polysaccharides. Geochim. Cosmochim. Acta 73, 3807-3818. https://doi.org/10.1016/j.gca.2009.02.036

Clausen, L., Fabricius, I., Madsen, L., 2001. Adsorption of pesticides onto quartz, calcite, kaolinite, and $\alpha$-alumina. J. Environ. Qual. 30, 846-857.

Cosmidis, J., Benzerara, K., Morin, G., Busigny, V., Lebeau, O., Jézéquel, D., Noël, V., Dublet, G., Othmane, G., 2014. Biomineralization of iron-phosphates in the water column of Lake Pavin (Massif Central, France). Geochim. Cosmochim. Acta 126, 7896. https://doi.org/10.1016/j.gca.2013.10.037

Cosmidis, J., Benzerara, K., Guyot, F., Skouri-Panet, F., Duprat, E., Férard, C., Guigner, J.M., Babonneau, F., Coelho, C., 2015. Calcium-phosphate biomineralization induced by alkaline phosphatase activity in Escherichia coli: Localization, kinetics, and potential signatures in the fossil record. Front. Earth Sci. 3, 84. https://doi.org/10.3389/feart.2015.00084

Costerton, J.W., Lewandowski, Z., Caldwell, D.E., Korber, D.R., Lappin-Scott, H.M., 1995. Microbial biofilms. Annu. Rev. Microbiol. 49, 711-745.

De Yoreo, J.J., Vekilov, P.G., 2003. Principles of crystal nucleation and growth. Rev. Mineral. Geochem. 54, 57-93.

Debela, F., Arocena, J.M., Thring, R.W., Whitcombe, T., 2010. Organic acid-induced release of lead from pyromorphite and its relevance to reclamation of $\mathrm{Pb}$-contaminated soils. Chemosphere 80, 450-456. https://doi.org/10.1016/j.chemosphere.2010.04.025

Eighmy, T.T., Shaw, E.L., Eusden Jr, J.D., Francis, C.A., 1998. Chloropyromorphite $\left(\mathrm{Pb}_{5}\left(\mathrm{PO}_{4}\right)_{3} \mathrm{Cl}\right)$ by XPS: an environmentally important secondary mineral. Surf. Sci. Spectra 5, 122-129.

Fein, J.B., Martin, A.M., Wightman, P.G., 2001. Metal adsorption onto bacterial surfaces: development of a predictive approach. Geochim. Cosmochim. Acta 65, 4267-4273. 
Flemming, H.-C., Wingender, J., 2010. The biofilm matrix. Nat. Rev. Microbiol. 8, 623-633. https://doi.org/10.1038/nrmicro2415

Flynn, T.M., Sanford, R.A., Ryu, H., Bethke, C.M., Levine, A.D., Ashbolt, N.J., Santo

Domingo, J.W., 2013. Functional microbial diversity explains groundwater chemistry in a pristine aquifer. BMC Microbiol. 13, 146.

Fransolet, A.-M., Jedwab, J., Tassel, R.V., 1978. Minéraux secondaires plombifères (cérusite, anglésite, pyromorphite, corkite et wulfénite) de Richelle, Belgique. Ann. Soc. Géol. Belg. 100, 1-7.

Ghiorse, W.C., 1984. Biology of iron-and manganese-depositing bacteria. Annu. Rev. Microbiol. 38, 515-550.

Ha, J., Gélabert, A., Spormann, A.M., Brown, G.E., 2010. Role of extracellular polymeric substances in metal ion complexation on Shewanella oneidensis: Batch uptake, thermodynamic modeling, ATR-FTIR, and EXAFS study. Geochim. Cosmochim. Acta 74, 1-15. https://doi.org/10.1016/j.gca.2009.06.031

Haefliger, P., Mathieu-Nolf, M., Lociciro, S., Ndiaye, C., Coly, M., Diouf, A., Faye, A.L., Sow, A., Tempowski, J., Pronczuk, J., Junior, A.P.F., Bertollini, R., Neira, M., 2009. Mass lead intoxication from informal used lead-acid battery recycling in Dakar, Senegal. Environ. Health Perspect. 117, 1535-1540. https://doi.org/10.1289/ehp.0900696

Hettiarachchi, G.M., Pierzynski, G.M., Ransom, M.D., 2001. In situ stabilization of soil lead using phosphorus. J. Environ. Qual. 30, 1214-1221.

Hunter, R.C., Beveridge, T.J., 2005. Application of a pH-sensitive fluoroprobe (C-SNARF-4) for $\mathrm{pH}$ microenvironment analysis in Pseudomonas aeruginosa biofilms. Appl. Environ. Microbiol. 71, 2501-2510. https://doi.org/10.1128/AEM.71.5.2501-2510.2005

Konhauser, K.O., 1998. Diversity of bacterial iron mineralization. Earth Sci. Rev. 43, 91-121. 
Laperche, V., Dictor, M.-C., Closel-Leloup, B., Baranger, P., 2004. Guide méthodologique du plomb appliqué à la gestion des sites et des sols pollués. BRGMRP-52881-FR, 136p., 40 ill.

Liang, X., Kierans, M., Ceci, A., Hillier, S., Gadd, G.M., 2016. Phosphatase-mediated bioprecipitation of lead by soil fungi. Environ. Microbiol. 18, 219-231. https://doi.org/10.1111/1462-2920.13003

Lothenbach, B., Ochs, M., Wanner, H., Yui, M., 1999. Thermodynamic data for the speciation and solubility of $\mathrm{Pd}, \mathrm{Pb}, \mathrm{Sn}, \mathrm{Sb}, \mathrm{Nb}$ and $\mathrm{Bi}$ in aqueous solution. JNC TN8400 99-011.

Miot, J., Benzerara, K., Morin, G., Kappler, A., Bernard, S., Obst, M., Férard, C., SkouriPanet, F., Guigner, J.-M., Posth, N., Galvez, M., Brown, G.E., Guyot, F., 2009. Iron biomineralization by anaerobic neutrophilic iron-oxidizing bacteria. Geochim. Cosmochim. Acta 73, 696-711. https://doi.org/10.1016/j.gca.2008.10.033

Penn, R.L., Banfield, J.F., 1998. Imperfect oriented attachment: dislocation generation in defect-free nanocrystals. Science 281, 969-971.

Pinchuk, G.E., Hill, E.A., Geydebrekht, O.V., De Ingeniis, J., Zhang, X., Osterman, A., Scott, J.H., Reed, S.B., Romine, M.F., Konopka, A.E., Beliaev, A.S., Fredrickson, J.K., Reed, J.L., 2010. Constraint-based model of Shewanella oneidensis MR-1 metabolism: A tool for data analysis and hypothesis generation. PLoS Comput. Biol. 6. https://doi.org/10.1371/journal.pcbi.1000822

Pinchuk, G.E., Geydebrekht, O.V., Hill, E.A., Reed, J.L., Konopka, A.E., Beliaev, A.S., Fredrickson, J.K., 2011. Pyruvate and lactate metabolism by Shewanella oneidensis MR-1 under fermentation, oxygen limitation, and fumarate respiration conditions. Appl. Environ. Microbiol. 77, 8234-8240. https://doi.org/10.1128/AEM.05382-11

Reith, F., Fairbrother, L., Nolze, G., Wilhelmi, O., Clode, P.L., Gregg, A., Parsons, J.E., Wakelin, S.A., Pring, A., Hough, R., Southam, G., Brugger, J., 2010. Nanoparticle 
factories: Biofilms hold the key to gold dispersion and nugget formation. Geology 38, 843-846.

Reith, F., Zammit, C.M., Shar, S.S., Etschmann, B., Bottrill, R., Southam, G., Ta, C., Kilburn, M., Oberthür, T., Ball, A.S., Brugger, J., 2016. Biological role in the transformation of platinum-group mineral grains. Nat. Geosci. 9, 294-298. https://doi.org/10.1038/ngeo2679

Rhee, Y.J., Hillier, S., Gadd, G.M., 2012. Lead transformation to pyromorphite by fungi. Curr. Biol. 22, 237-241. https://doi.org/10.1016/j.cub.2011.12.017

Rhee, Y.J., Hillier, S., Pendlowski, H., Gadd, G.M., 2014. Pyromorphite formation in a fungal biofilm community growing on lead metal. Environ. Microbiol. 16, 1441-1451. https://doi.org/10.1111/1462-2920.12416

Rouxhet, P.G., Mozes, N., Dengis, P.B., Dufrêne, Y.F., Gerin, P.A., Genet, M.J., 1994. Application of X-ray photoelectron spectroscopy to microorganisms. Colloids Surf. B 2, $347-369$.

Roy, S., Gaillardet, J., Allègre, C.J., 1999. Geochemistry of dissolved and suspended loads of the Seine River, France: anthropogenic impact, carbonate and silicate weathering. Geochim. Cosmochim. Acta 63, 1277-1292. https://doi.org/10.1016/S00167037(99)00099-X

Ruby, M.V., Davis, A., Nicholson, A., 1994. In situ formation of lead phosphates in soils as a method to immobilize lead. Environ. Sci. Technol. 28, 646-654. https://doi.org/10.1021/es00053a018

Scofield, J.H., 1976. Hartree-Slater subshell photoionization cross-sections at 1254 and 1487 eV. J. Electron Spectrosc. Relat. Phenom. 8, 129-137.

Sparks, D.L., 2005. Toxic metals in the environment: the role of surfaces. Elements 1, 193197. 
Stewart, P.S., Franklin, M.J., 2008. Physiological heterogeneity in biofilms. Nat. Rev.

Microbiol. 6, 199-210. https://doi.org/10.1038/nrmicro1838

Templeton, A.S., Trainor, T.P., Traina, S.J., Spormann, A.M., Brown, G.E., 2001. Pb(II)

distributions at biofilm-metal oxide interfaces. Proc. Natl. Acad. Sci. USA 98, 1189711902.

Templeton, A.S., Spormann, A.M., Brown, G.E., 2003. Speciation of Pb(II) sorbed by

Burkholderia cepacia /goethite composites. Environ. Sci. Technol. 37, 2166-2172. https://doi.org/10.1021/es026081b

Toner, B.M., Santelli, C.M., Marcus, M.A., Wirth, R., Chan, C.S., McCollom, T., Bach, W., Edwards, K.J., 2009. Biogenic iron oxyhydroxide formation at mid-ocean ridge hydrothermal vents: Juan de Fuca Ridge. Geochim. Cosmochim. Acta 73, 388-403.

Topolska, J., Latowski, D., Kaschabek, S., Manecki, M., Merkel, B.J., Rakovan, J., 2014. Pb remobilization by bacterially mediated dissolution of pyromorphite $\mathrm{Pb}_{5}\left(\mathrm{PO}_{4}\right)_{3} \mathrm{Cl}$ in presence of phosphate-solubilizing Pseudomonas putida. Environ. Sci. Pollut. Res. Int 21, 1079-1089. https://doi.org/10.1007/s11356-013-1968-3

U.S. Geological Survey, 2017. Miner. Commod. Summ. 2017 US Geol. Surv. 202. https://doi.org/10.3133/70180197.

U.S. Geological Survey, 2015. Miner. Commod. Summ. 2015 US Geol. Surv. 196. http://dx.doi.org/10.3133/70140094.

van Hullebusch, E.D., Zandvoort, M.H., Lens, P.N.L., 2003. Metal immobilisation by biofilms: Mechanisms and analytical tools. Rev. Environ. Sci. Biotechnol. 2, 9-33. https://doi.org/10.1023/B:RESB.0000022995.48330.55

Wang, Y., Gélabert, A., Michel, F.M., Choi, Y., Eng, P.J., Spormann, A.M., Brown, G.E., 2016. Effect of biofilm coatings at metal-oxide/water interfaces II: Competitive sorption between $\mathrm{Pb}(\mathrm{II})$ and $\mathrm{Zn}(\mathrm{II})$ at Shewanella oneidensis /metal-oxide/water interfaces. Geochim. Cosmochim. Acta 188, 393-406. https://doi.org/10.1016/j.gca.2016.04.054 
Weiner, S., Dove, P.M., 2003. An overview of biomineralization processes and the problem of the vital effect. Rev. Mineral. Geochem. 54, 1-29.

Wingender, J., Jaeger, K.-E., 2002. in Encyclopedia of Environmental Microbiology (ed. Bitton, G.) 1207-1223 (Wiley, New York).

Wu, S.C., Luo, Y.M., Cheung, K.C., Wong, M.H., 2006. Influence of bacteria on Pb and Zn speciation, mobility and bioavailability in soil: A laboratory study. Environ. Pollut. 144, 765-773. https://doi.org/10.1016/j.envpol.2006.02.022

Xie, L., Giammar, D.E., 2007. Equilibrium solubility and dissolution rate of the lead phosphate chloropyromorphite. Environ. Sci. Technol. 41, 8050-8055. https://doi.org/10.1021/es071517e

Yoon, T.H., Trainor, T.P., Eng, P.J., Bargar, J.R., Brown, G.E., 2005. Trace metal ion partitioning at polymer film-metal oxide interfaces: Long-period X-ray standing wave study. Langmuir 21, 4503-4511. https://doi.org/10.1021/la047271y 


\section{Table legends}

\section{Table 1}

Experimental conditions used during the lead-exposure experiments and associated analysis. Values 1 and 0 indicate the presence and absence of biofilm in the experiments, respectively.

\section{Table 2}

Lead relative abundances $d_{P b}$ derived from XPS measurements on biofilms exposed to different $\mathrm{Pb}^{2+}$ concentrations for various exposure times in the mineralization medium. Abundance of $\mathrm{Pb}$ and $\mathrm{Al}$ are used to calculate the biofilm coverage $\theta$ on alumina substrate, as detailed in text.

\section{Figure captions}

Fig. 1. Saturation indexes of lead-bearing mineral phases as a function of $\mathrm{pH}$ in the mineralization medium at a total $\mathrm{Pb}^{2+}$ concentration of (a) $10^{-4} \mathrm{M}$, (b) $10^{-6} \mathrm{M}$, and (c) $10^{-7} \mathrm{M}$ and in $10^{-2} \mathrm{M} \mathrm{NaNO}_{3}$ solution with total $\mathrm{Pb}^{2+}$ concentrations of (d) $10^{-4} \mathrm{M}$, and (e) $10^{-6} \mathrm{M}$. While all the $\mathrm{Pb}$-bearing phases available in the Thermoddem database were considered for thermodynamic calculations, only the most representative mineral species are represented here. They include cerussite $\mathrm{PbCO}_{3}$ (blue squares) (however masked by $\mathrm{Pb}(\mathrm{OH})_{2}$ in (d) and (e)), hydrocerussite $\mathrm{Pb}\left(\mathrm{CO}_{3}\right)_{2}(\mathrm{OH})_{2}$ (red circles), lead hydroxide $\mathrm{Pb}(\mathrm{OH})_{2}$ (green rhombus), wulfenite $\mathrm{PbMoO}_{4}$ (black triangles) and litharge $\mathrm{PbO}$ (grey cross). Note that, in theory, the absence of phosphate ions in the mineralization medium, and hence in the modeling, prevents the formation of pyromorphite $\mathrm{Pb}_{5}\left(\mathrm{PO}_{4}\right)_{3}(\mathrm{OH})$. Atmospheric $\mathrm{CO}_{2}$ partial pressure $\left(\mathrm{pCO}_{2}\right)$ was set at 0.00038 atm to include an atmospheric contribution to the carbonate system. 
Fig. 2. SEM micrographs of $S$. oneidensis $\mathrm{MR}-1$ biofilm exposed to $10^{-7} \mathrm{M} \mathrm{Pb}^{2+}$ for $24 \mathrm{~h}$ in the mineralization medium. (a) secondary electron micrograph showing cells (green arrows) encased in an organic matrix. (b) associated FIB-SEM-SE cross-section showing on top of the alumina substrate, the biofilm structure formed of cells (green arrows), large pores (blue arrow) and organic exopolymers (red arrow).

Fig. 3. SEM micrographs of FIB-milled cross-sections of S. oneidensis MR-1 biofilms exposed to lead concentrations of (a) $10^{-4} \mathrm{M}$ (SEM-SE image) and (b) $10^{-6} \mathrm{M}$ (SEM-BSE image) for $24 \mathrm{~h}$ in experiments performed in $10^{-2} \mathrm{M} \mathrm{NaNO}_{3}$ solution. In (a), minerals are covering the surface of the biofilm (zone 1), but are also found in the denser inner part of the biofilm (zone 2). In contrast, in (b), whereas stranded-like lead-bearing structures have precipitated between bacterial cells on top of the organic structure (zone 1), no $\mathrm{Pb}$ precipitates are visible close to the $\alpha-\mathrm{Al}_{2} \mathrm{O}_{3}$ substrate (zone 2).

Fig. 4. XPS spectra for (a) C 1s and (b) Pb 4f core levels collected on a S. oneidensis MR-1 biofilm exposed for $1 \mathrm{~h}$ to the mineralization medium supplemented with $10^{-4} \mathrm{M} \mathrm{of}^{2+}$. Deconvolution and background are reported as dashed and dotted lines, respectively.

Fig. 5. SEM-BSE (a) and TEM (b) micrographs of S. oneidensis MR-1 biofilm exposed to $10^{-6}$ $\mathrm{M}$ of $\mathrm{Pb}^{2+}$ for $24 \mathrm{~h}$ in the mineralization medium. (c) SEM-BSE image of S. oneidensis MR-1 biofilm exposed to $10^{-4} \mathrm{M}$ of $\mathrm{Pb}^{2+}$ for $1 \mathrm{~h}$ in the $\mathrm{NaNO}_{3}$ solution. (d) EDXS spectrum of the mineral designated by the red arrow accompanied with a red dot in (b). The joint $\mathrm{Pb}$ and $\mathrm{P}$ signal and the absence of Mo suggest the presence of a polymorphous form of pyromorphite, a lead phosphate. A similar signal was found for the mineral phases depicted in (a) and (b). Asterisks indicate peaks characteristic of $\mathrm{Cu}$ emerging from the TEM grid. 
Fig. 6. SEM micrographs of wulfenite octahedron minerals (shown by yellow dashed arrows) within a biofilm of $S$. oneidensis MR-1 grown on alumina substrates and exposed to $\mathrm{Pb}^{2+}$ at $10^{-6} \mathrm{M}$ for (a) and (b) and $10^{-7} \mathrm{M}$ for (c) and (d) in the mineralization medium for 7 days (168 h). With the exception of (b) collected in BSE mode, all are SEM-SE images. Imprints of bacteria are visible at the crystal surface, while such rod-shaped morphologies are not present in the corresponding abiotic experiment (Supplementary data Fig. A1). (a) shows in addition a FIB-milled section of wulfenite. Note in (b) the presence of nanometric pyromorphite precipitates indicated by a red arrow. (e) Associated SAED pattern. (f) EDXS spectrum collected on the crystal designated with the arrow accompanied with a dot in panel (c); asterisks indicate peaks characteristic of $\mathrm{Cu}$ emerging from the TEM grid.

Fig. 7. ICP-QMS concentrations as a function of time (t) of (a) lead, and (b) molybdenum concentrations in the supernatant for $\mathrm{Pb}$-exposure experiments performed using $\mathrm{S}$. oneidensis MR-1 biofilms and initial lead concentrations of $10^{-7} \mathrm{M}$ (red squares) and $10^{-6} \mathrm{M}$ (blue triangles). Associated thermodynamic modeling considering only sorption (dashed) or allowing precipitation of pyromorphite and wulfenite (dashed) is represented with horizontal lines. Blue and red refer to initial lead concentrations of $10^{-6} \mathrm{M}$ and $10^{-7} \mathrm{M}$, respectively. The thick dashed middle line represents the average values of six models obtained at $\mathrm{pH} 6,6.5$ and 7 and phosphate concentrations varying between $1.5 \cdot 10^{-3}$ and $3 \cdot 10^{-5} \mathrm{M}$. Thin lines correspond to the associated standard deviation (not distinguishable from the average line in (a) for both initial lead concentrations). Blue and red dotted lines are overlapping in (a). Measured $\mathrm{MoO}_{4}{ }^{2-}$ concentrations are in the range of computed concentrations for $\mathrm{MoO}_{4}{ }^{2-}$. This range includes the concentration expected for sorption only but also when precipitation of pyromorphite and wulfenite are allowed since they imply no significant variation. 
Fig. 8. TEM micrographs of $S$. oneidensis $\mathrm{MR}-1$ biofilms exposed to a $\mathrm{Pb}^{2+}$ concentration of $10^{-4} \mathrm{M}$ for $24 \mathrm{~h}$ in experiments performed in $10^{-2} \mathrm{M} \mathrm{NaNO}_{3}$ solution. (a) dense cubes identified as cerussite (zone 1) closely associated with smaller electron-dense aggregates identified as pyromorphite (zone 2). (b) closest view of the pyromorphite nanocrystals (zone 5). (c) precipitation of pyromorphite occurring on bacterial cells and presenting various crystal sizes (zones 3 and 4). (d-e) EDXS spectrum and SAED pattern of the mineral phases displayed in zone 1 for (d) and in zones 2 to 4 for (e).

\section{APPENDIX}

Table A1. Equilibrium constants considered for thermodynamic calculations in the mineralization medium.

Figure A1. (a) SEM-SE observations of the product of the abiotic control experiment performed during $24 \mathrm{~h}$ using the mineralization medium supplemented with $10^{-6} \mathrm{M} \mathrm{Pb}^{2+}$ in the absence of biofilm. It shows the presence of the thermodynamically-predicted wulfenite $\mathrm{PbMoO}_{4}$. (b) associated EDXS spectrum. The carbon signal arises from the C-coating.

Figure A2. Raman spectrum of the wulfenite mineral obtained after $168 \mathrm{~h}$ of lead exposure of the bacterial biofilm using the mineralization medium supplemented with $10^{-6} \mathrm{M} \mathrm{Pb}^{2+}$. Experimental data and a reference spectrum from the RRUFF database (http://rruff.info/) are reported in black and red, respectively. 
Table 1

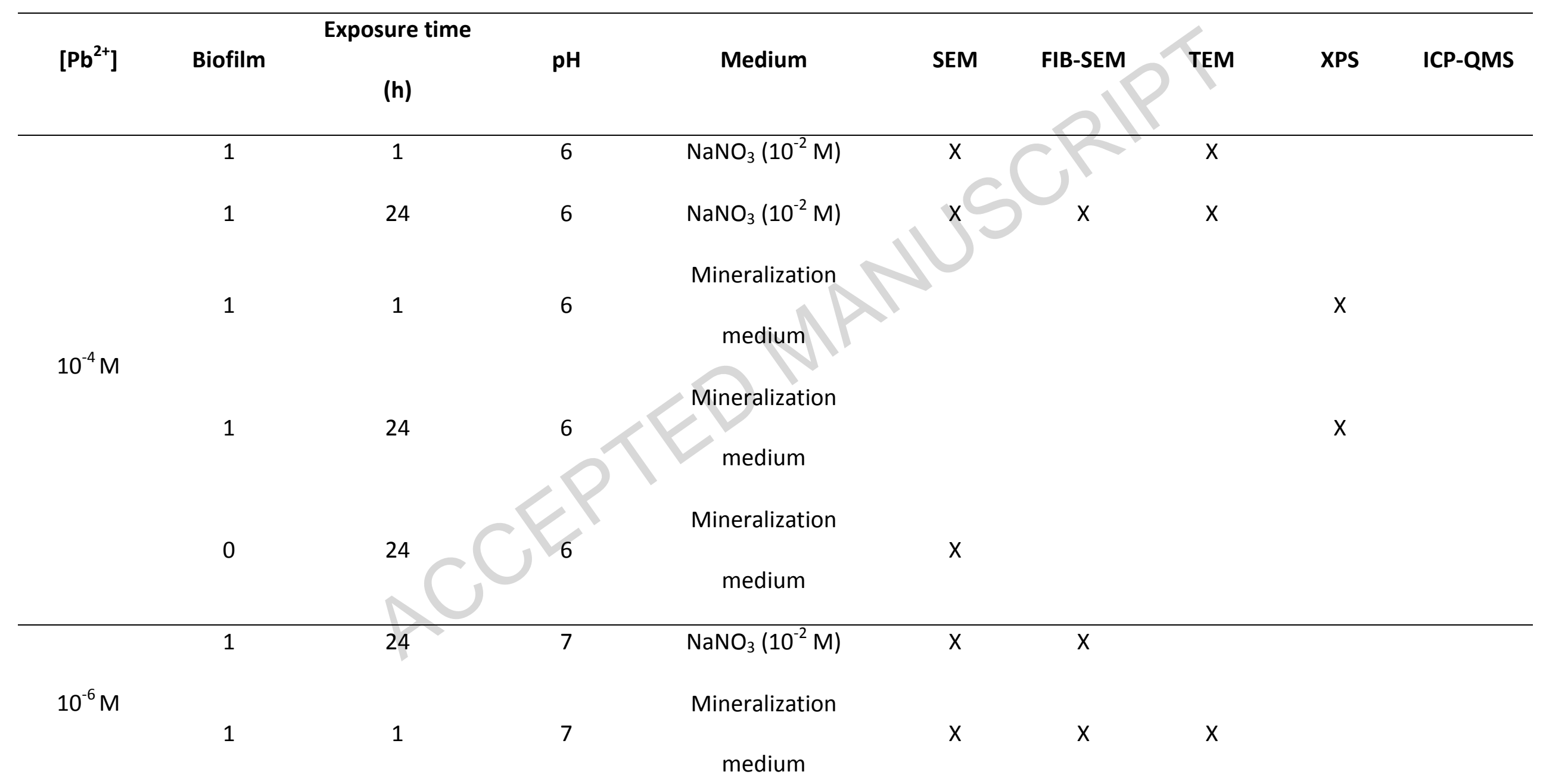


1

0

$10^{-7} \mathrm{M}$
1

24

0

1

168

0

24

168

68

24

1

168
7

\author{
medium
}

Mineralization

Mineralization

medium

Mineralization

medium

Mineralization

medium

Mineralization

medium

Mineralization

7
X

X

X

X

X

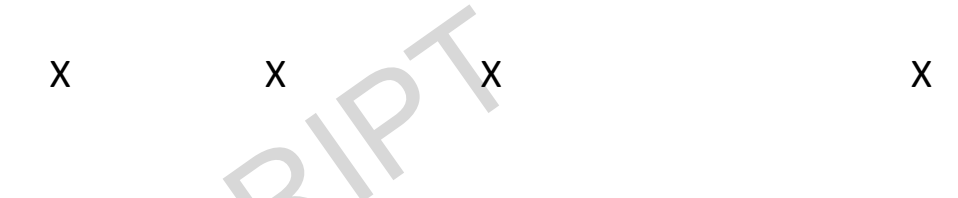

$x$

X

medium 
Table 2

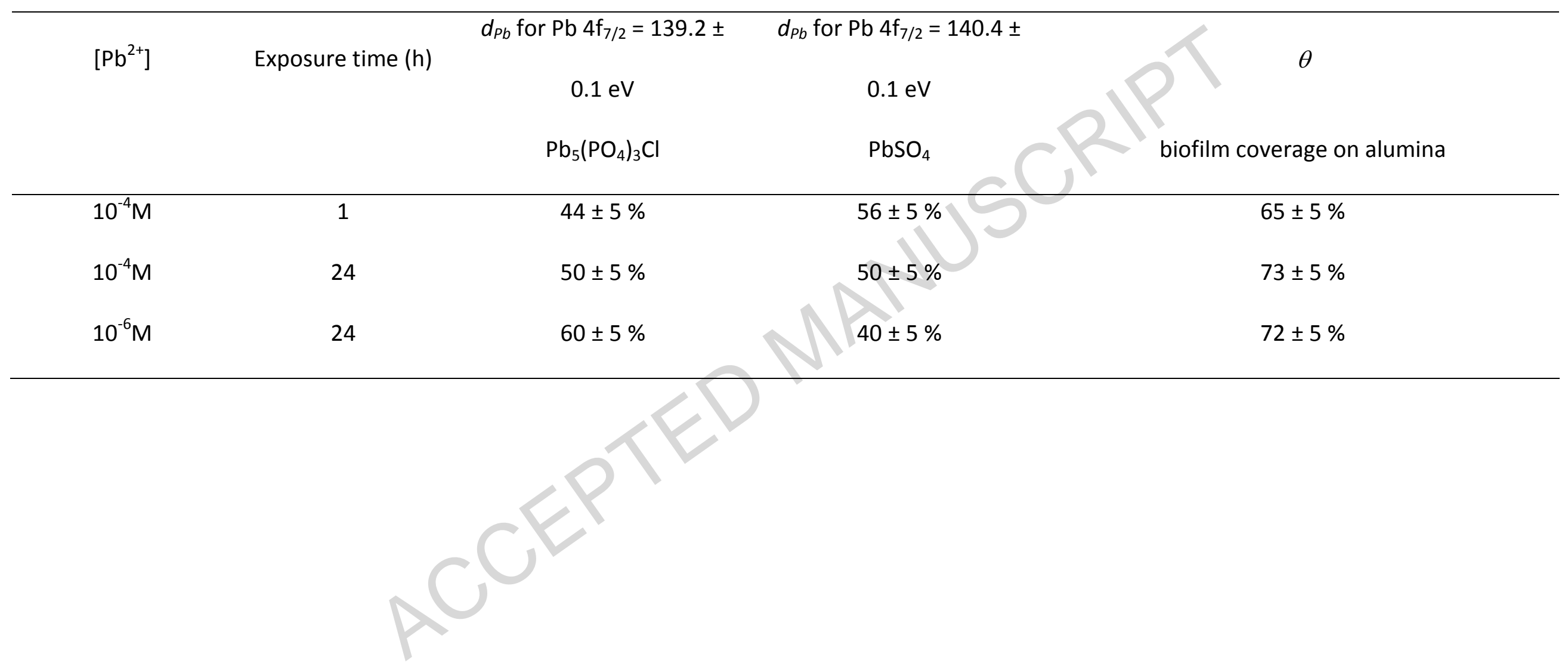




\section{Highlights}

- Biofilm activity drives pyromorphite $\left(\mathrm{Pb}_{5}\left(\mathrm{PO}_{4}\right)_{3} \mathrm{Cl}\right)$ precipitation

- The thermodynamically-stable wulfenite formation is delayed in biofilm

- Focused ion beam milled sections of the biofilm reveal gradients in lead biomineralization 


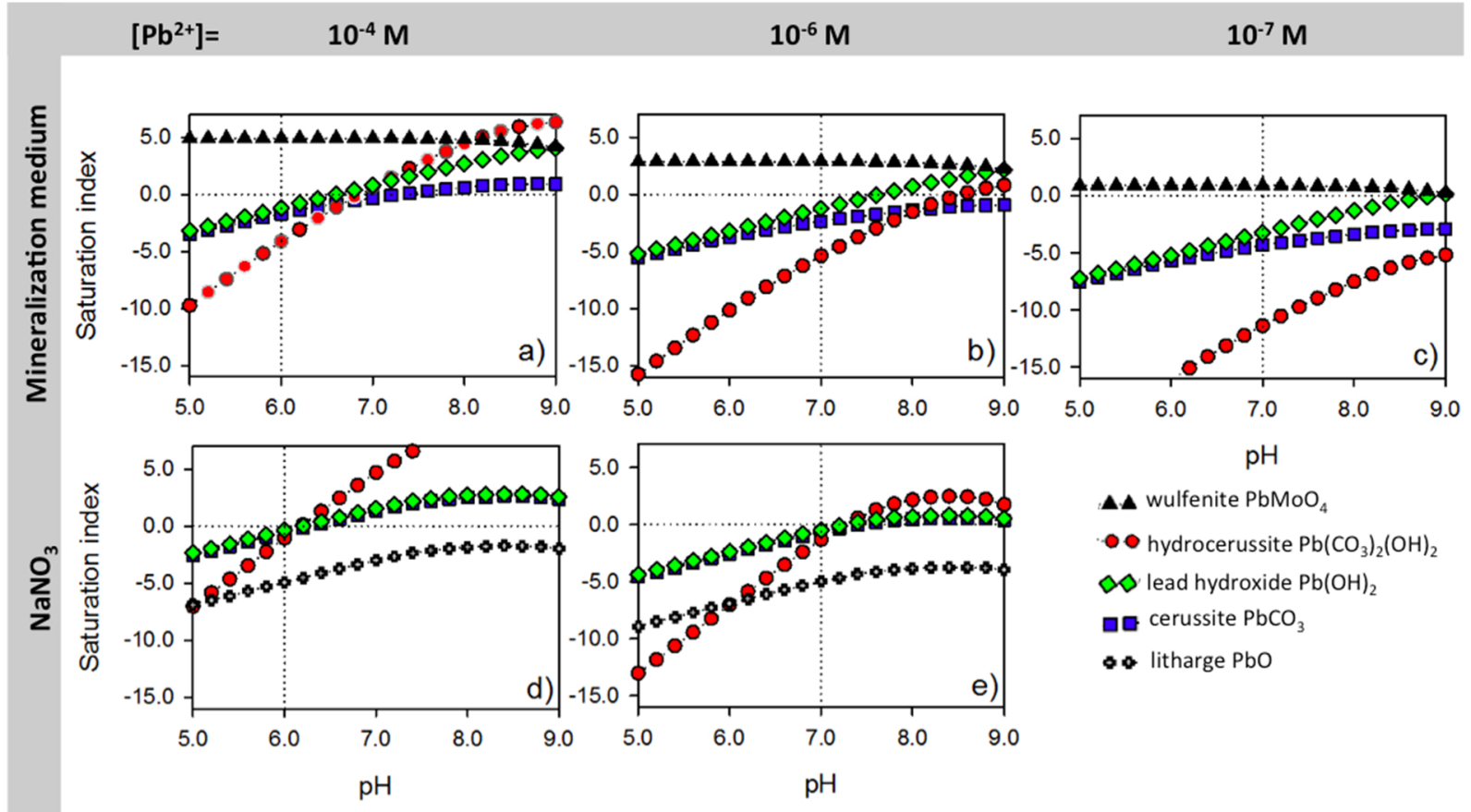

Figure 1 


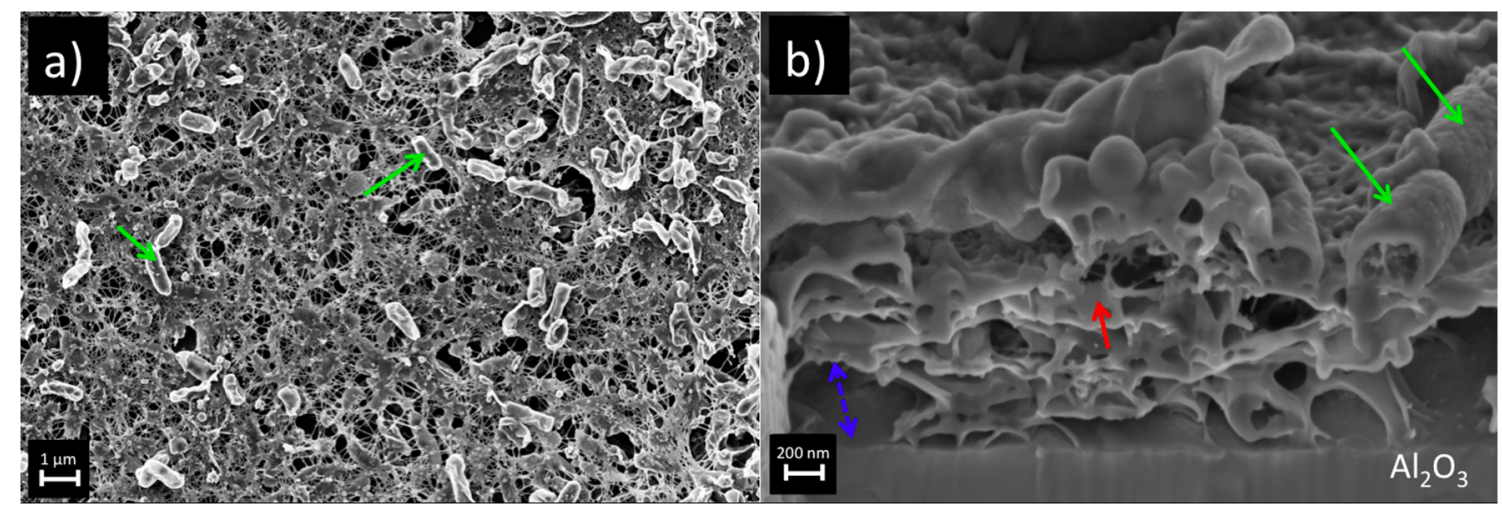

Figure 2 


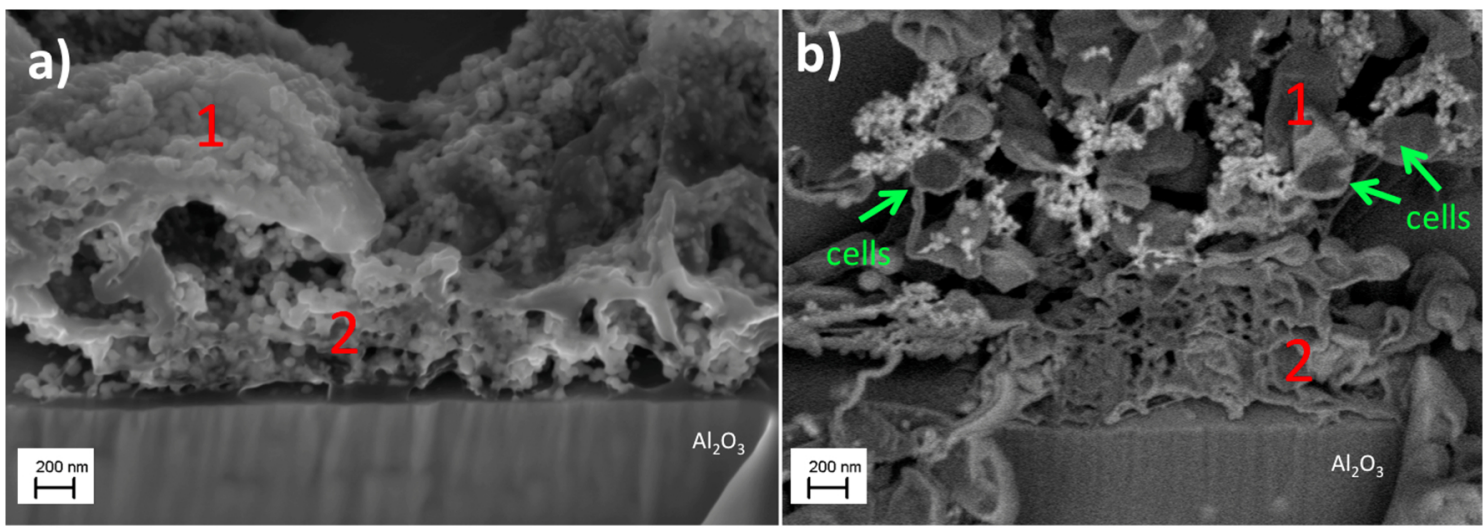

Figure 3 

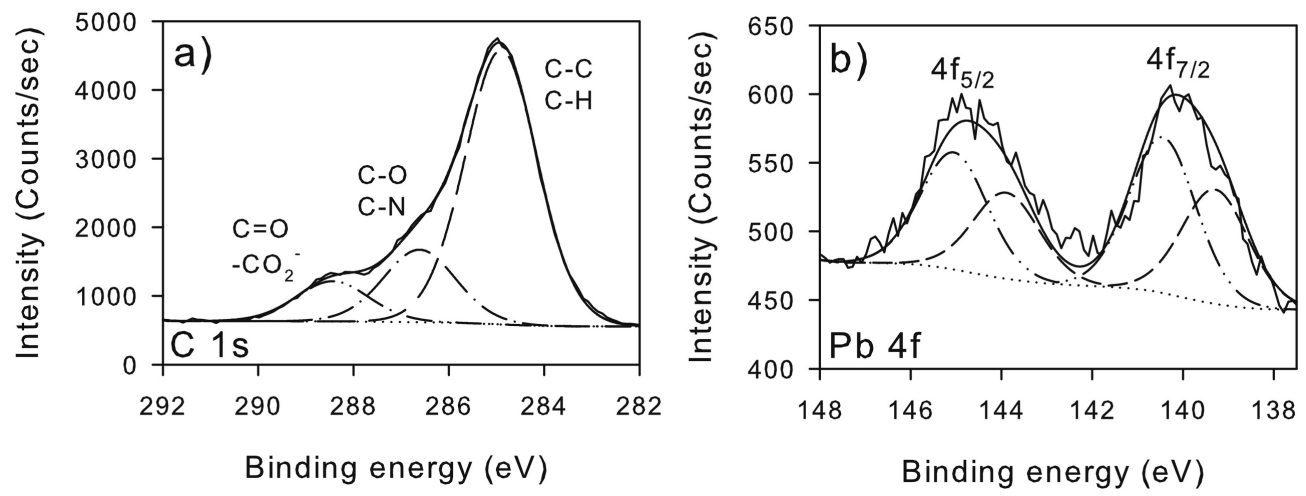

Figure 4 
a)

b)

$\uparrow$

$\pi$

$10 \mu \mathrm{m}$

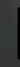

$100 \mathrm{~nm}$

cell
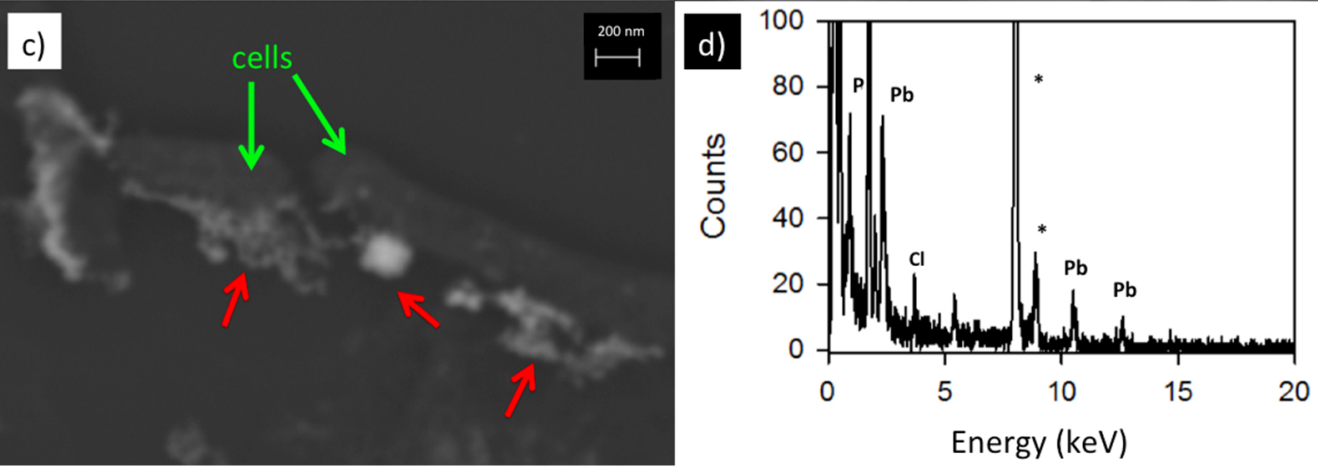

Figure 5 


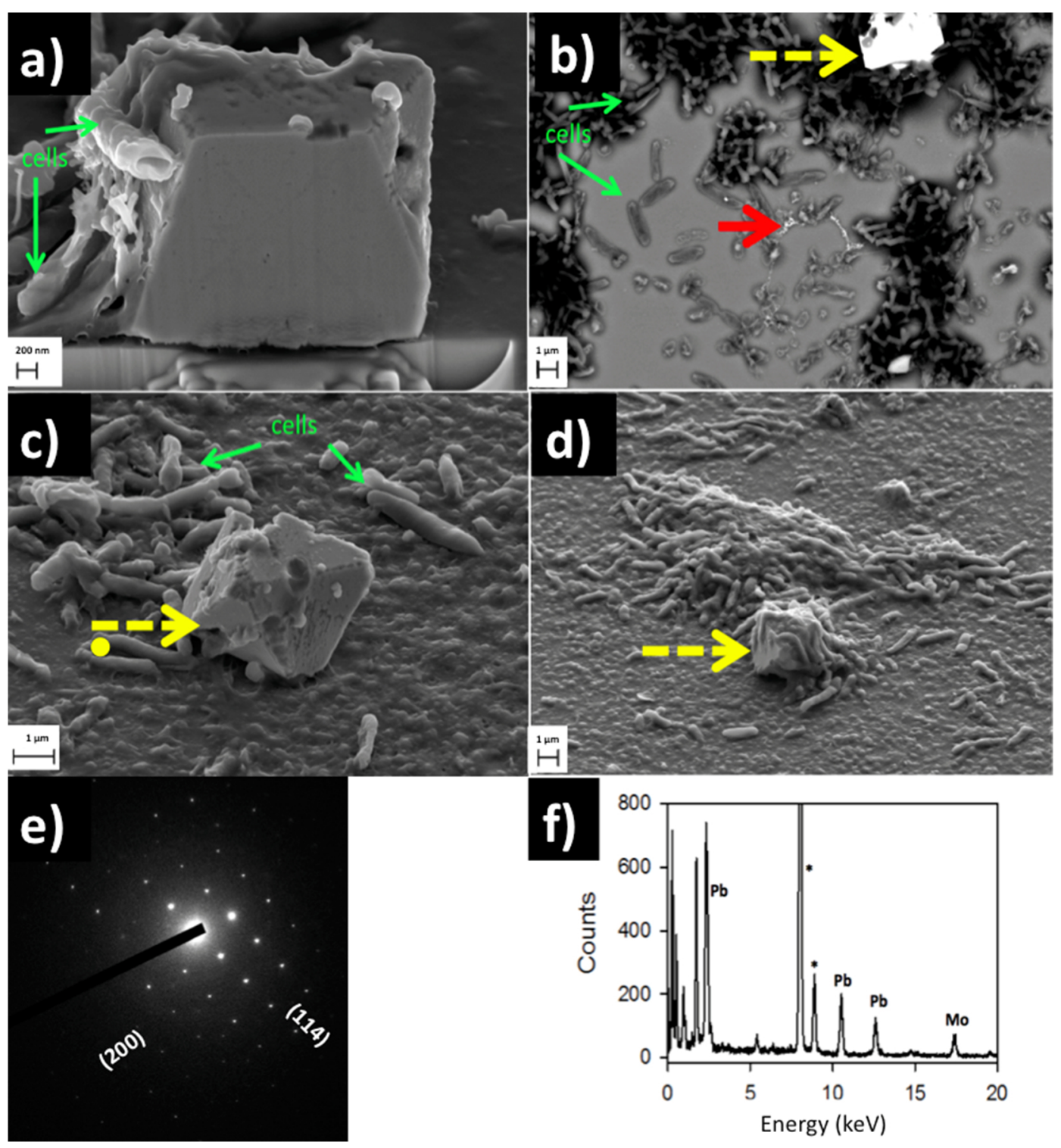

Figure 6 

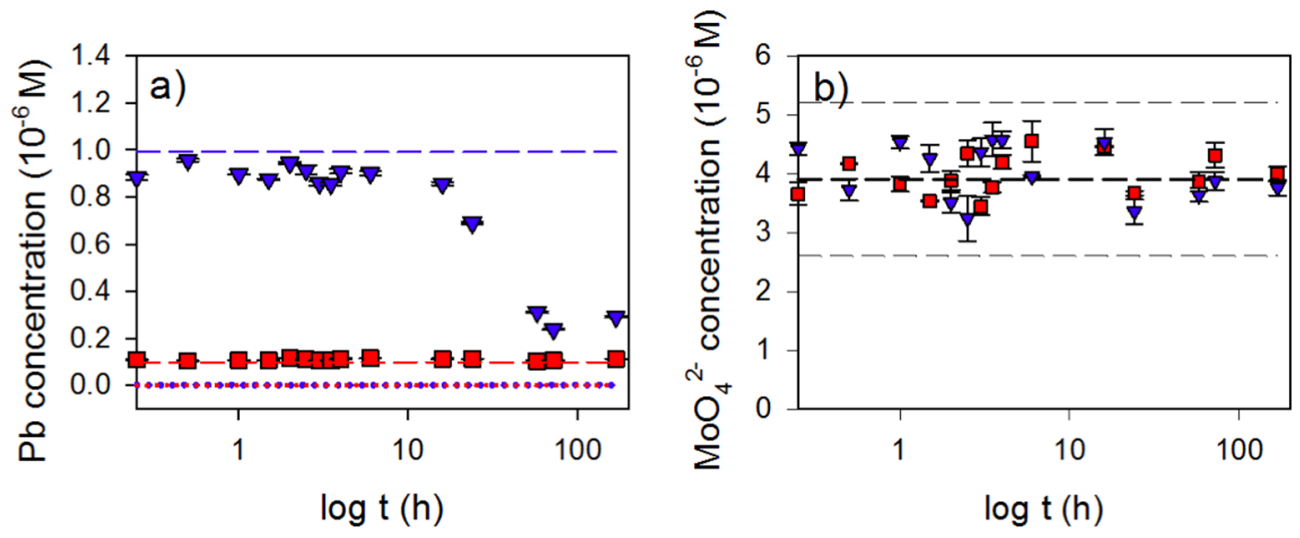

Thermodynamic model

二三 : Precipitation not allowed (sorption)

$\ldots$. : Precipitation allowed

Figure 7 


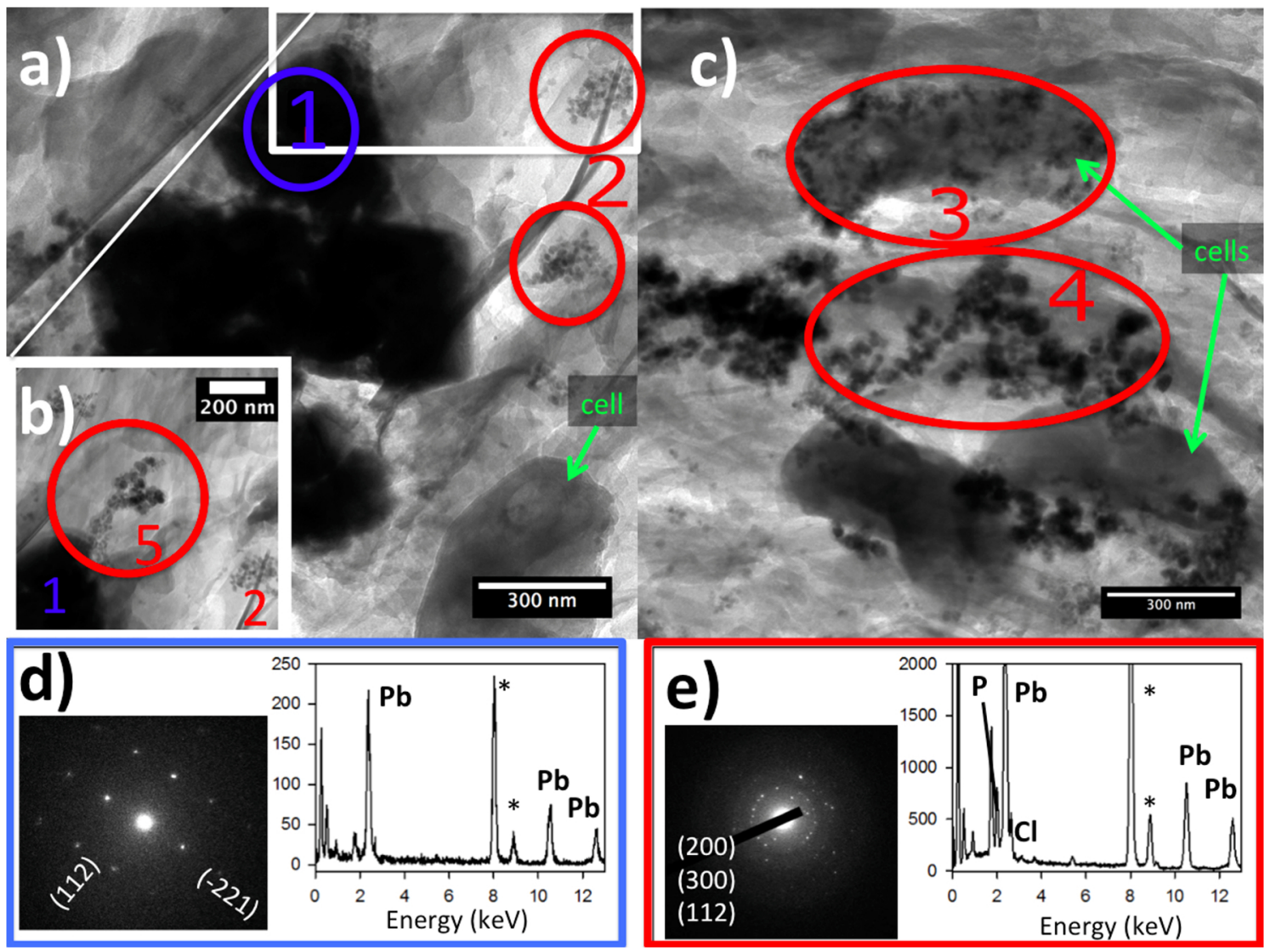

Figure 8 


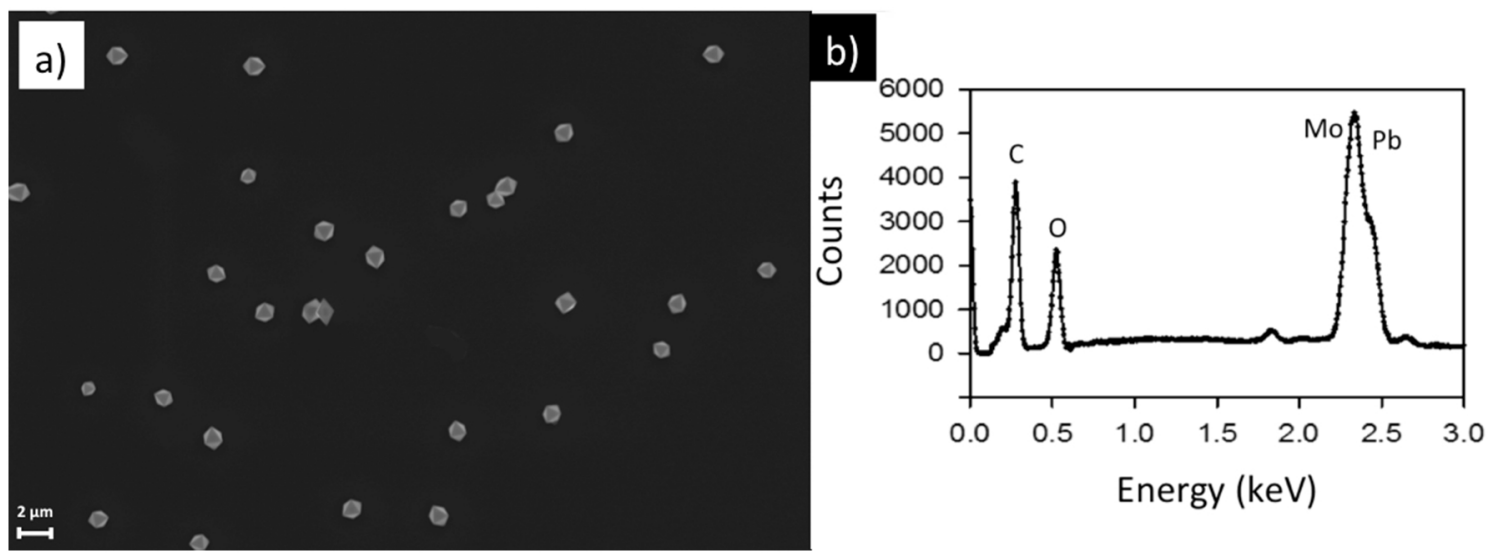

Figure 9 


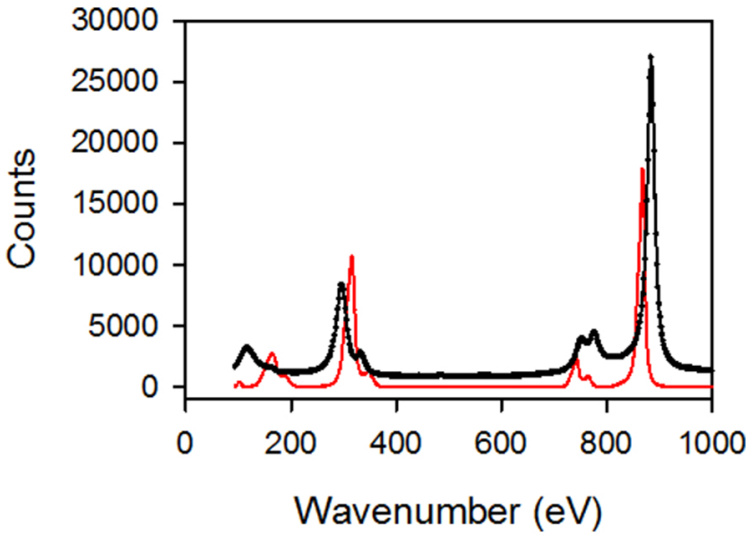

Figure 10 